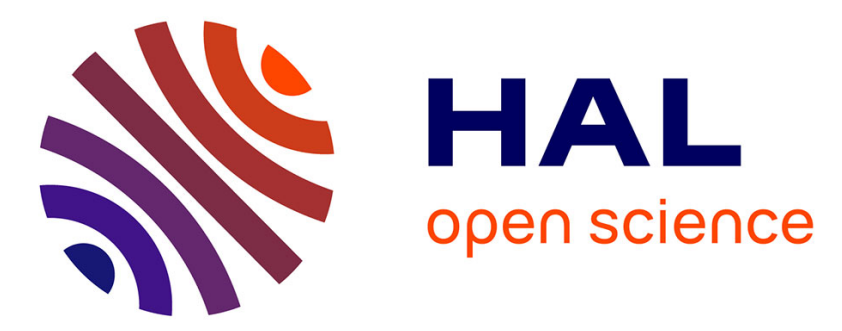

\title{
Performance of the Phytoplankton Index for Lakes (IPLAC): A multimetric phytoplankton index to assess the ecological status of water bodies in France
}

Christophe Laplace-Treyture, T. Feret

\section{- To cite this version:}

Christophe Laplace-Treyture, T. Feret. Performance of the Phytoplankton Index for Lakes (IPLAC): A multimetric phytoplankton index to assess the ecological status of water bodies in France. Ecological Indicators, 2016, 69, pp.686-698. 10.1016/j.ecolind.2016.05.025 . hal-02167882

\section{HAL Id: hal-02167882 \\ https://hal.science/hal-02167882}

Submitted on 28 Jun 2019

HAL is a multi-disciplinary open access archive for the deposit and dissemination of scientific research documents, whether they are published or not. The documents may come from teaching and research institutions in France or abroad, or from public or private research centers.
L'archive ouverte pluridisciplinaire HAL, est destinée au dépôt et à la diffusion de documents scientifiques de niveau recherche, publiés ou non, émanant des établissements d'enseignement et de recherche français ou étrangers, des laboratoires publics ou privés. 


\title{
Performance of the Phytoplankton Index for Lakes (IPLAC): a multimetric phytoplankton index to assess the ecological status of water bodies in France
}

\author{
Christophe Laplace-Treyture ${ }^{1}$, Thibaut Feret ${ }^{1}$ \\ ${ }^{1}$ Irstea, UR EABX, 50 avenue de Verdun, F-33612 Cestas Cedex, France.
}

\begin{abstract}
A new phytoplankton-based index was designed to respond to the Water Framework Directive (WFD) requirements concerning the assessment of lake ecological status. The "Indice Phytoplancton Lacustre" (IPLAC) is a multimetric index, taking into account biomass, abundance and species composition of communities. The first metric is based on the total phytoplankton biomass (MBA), the second on the abundance and taxonomic composition (MCS) of 165 indicator taxa. The IPLAC was developed on 2 independent databases, one for the calibration and the second for the validation of the metrics. The calibration dataset was composed of 255 "lake-years" from 214 distinct lakes sampled between 2005 and 2012. The validation dataset included 173 lake-years in order to confirm the response of the index to the trophic gradient and anthropogenic pressure.

The results show that the IPLAC correctly highlights chemical pressure (eutrophication). Especially high Pearson correlations are shown with total phosphorus $(r=-0.71, p$-value $<0.001)$, chlorophyll-a ( $r=-0.83, p$-value $<0.001)$ and water transparency $(r=0.73, p$-value $<0.001)$ which are the main proxies for the trophic level. Corine land cover was used as an indication of the anthropogenic pressure and good correlations are also found with the watershed land use, negatively correlated with agricultural area $(r=-0.60, p$-value $<0.001)$, population density $(r=-0.36, p$-value $<0.001)$ and positively with forest area $(r=0.57$, $p$-value $<0.001)$.

The index is WFD-compliant and is dedicated to natural lakes and artificial water bodies in metropolitan France, and will be routinely used by the French Ministry of the Environment to assess lake ecological status through the phytoplankton community. However, the results must be carefully interpreted in two cases: reservoirs with large water level fluctuations, and samples that include less than 5 indicator species.
\end{abstract}


Keywords: phytoplankton, ecological status, lake, multimetric index, chlorophyll, specific composition, France.

\section{Introduction}

Since 2000, the WFD - Water Framework Directive (European Parliament, 2000) - obliges Member States to implement tools to assess the ecological status of water bodies. This common goal requires assessment of the ecological status of water resources through the development of biological indices and not simple chemical analyses. The WFD requires that the ecological status of lakes be judged by the use of four major biological elements including the phytoplankton community. In this context, phytoplankton-based indices must be developed, taking into account biomass, abundance, species composition of communities, frequency and intensity of blooms (European Parliament, 2000).

At the European level several national methods have already been proposed: the German Phyto Lake Index (PSI) (Mischke et al., 2008), the Brettum index in Austria (Brettum, 1989; Dokulil et al., 2005; Wolfram et al., 2011), the Phytoplankton Trophic index (PTI) in UK (Phillips et al., 2012). All these methods are based on similar standardized sampling protocols and use 3 to 6 surveys per year, during the phytoplankton growing period, to assess the ecological status of lakes.

The trophic level is determined by the nutrient load reached in a lake. Thus it is complex to evaluate as it depends on many parameters including phosphorus as the main trigger and also nitrogen (OECD, (1982). Some authors (Fabbro et al. (2000), Salmaso (2003) and Coste et al. (2009)) derived a trophic index from the axes of a Principal Component Analysis (PCA) based on a group of paramaters representative of this gradient. Others (Ptacnik et al., 2009) use total phosphorus as an indicator of the gradient, as it was decided by the European intercalibration expert groups (GIG) dedicated to lake ecological status assessment (European Commission, 2011). Hence, most of the indices developed for lake assessment in respect to WFD requirements, evaluate the trophic status of water bodies using the total phosphorus as a proxy (de Hoyos et al., 2014; Phillips et al., 2014; Wolfram et al., 2014).

None of the phytoplankton-based European indices cited above are adapted to the high diversity of French lakes (highly variable climate, relief, anthropogenic impact, and artificial or natural type). That is why in 2007 the development of a multimetric phytoplankton index applicable to all French lakes was initiated. The index had to be compliant with the WFD requirements. It must be based on the taxonomic composition of phytoplankton and must highlight eutrophication through total phosphorus contents, in order to be comparable with other European indices. Although a 
phytoplankton index $\left(I_{P L}\right)$, developed in 1990 and revised in 2003 (Barbe et al., 2003a; Barbe et al., 2003b; Barbe et al., 1990) already existed, this old index was neither WFD compliant nor multimetric. Thus substantial improvements had to be done to obtain a new index.

The aim of the study is to present the different steps in the development of the IPLAC ("Indice Phytoplancton Lacustre"), a new phytoplankton index dedicated to assess the ecological status of lakes and reservoirs of the whole French metropolitan hydrosystem (not applicable to overseas water bodies). Based on a large database, the index was designed in two complementary metrics based on phytoplankton biomass and taxonomic composition, using calibration and validation datasets. The ability of IPLAC to reveal different pressure gradients is also discussed, with recommendations for managers who should be routinely using this index.

\section{Materials and methods}

\subsection{Sampling methods and acquisition of environmental data}

In order to develop the phytoplankton index, the first step consisted in creating a large lake database at a national level. The data were collected by the water agencies between 2005 and 2012 according to a standardized sampling method (Laplace-Treyture et al., 2009) which recommends a survey at each season (winter to autumn) with 3 during the growing season (May to October). The surveys should be separated by one month, at minimum, in order to be clearly different and thus representing the growing season. The sampling must be performed at one point in the deepest part of the lake and the sample must integrate the whole euphotic zone. Taxa are determined at the species level with an inverted microscope and results are expressed in biovolume using standard cell values defined in the software Phytobs (Hadoux et al., 2015) or when the standard cell values are missing directly from calculation onto the sample. The counting process followed European Standard NF15204 (2006) as specified by Laplace-Treyture et al. (2009). Water chemistry samples were also collected from the euphotic zone at the same time. Total phosphorus (TP) and chlorophyll were analyzed by the standard methods NF EN ISO 6878 (2004) and NF-T 90-117 (1999) respectively. Environmental data such as Secchi depth were measured during each phytoplankton campaign. The physical characteristics of the lakes (Table 2) were provided by water agencies from GIS and bathymetric studies. The land use and watershed areas were calculated from Corine Land Cover database (European Union, 2006). The first classification level of Corine Land Cover was used to determine 5 classes of land use: agricultural, intensive agricultural, forest, artificial, wet area. Population density was also added using Corine Land Cover 2000 (European Union, 2000). 


\subsection{Datasets}

The database includes 290 sites (Figure 1), including 28 reference sites, which are defined following a specific approach with emphasis on land use (Corine Land Cover). Such reference sites are considered to be slightly or not impacted by human pressure (European Parliament, 2000). The criteria selected are detailed in Ministère de l'Écologie et du Développement Durable (2004). The watershed should have more than $90 \%$ of natural land cover (forest, wet area) and intensive agricultural should be absent. No urban or industrial discharges are permitted.

The surveys used for the index development were conducted at each season with 3 during the growing period (May-October). Phytoplankton samples with less than 5 taxa determined were omitted, the samples being considered as incomplete and not representative of the whole phytoplankton community. We called a "lake-year" a year of survey (at least 3 campaigns) for a specific lake.

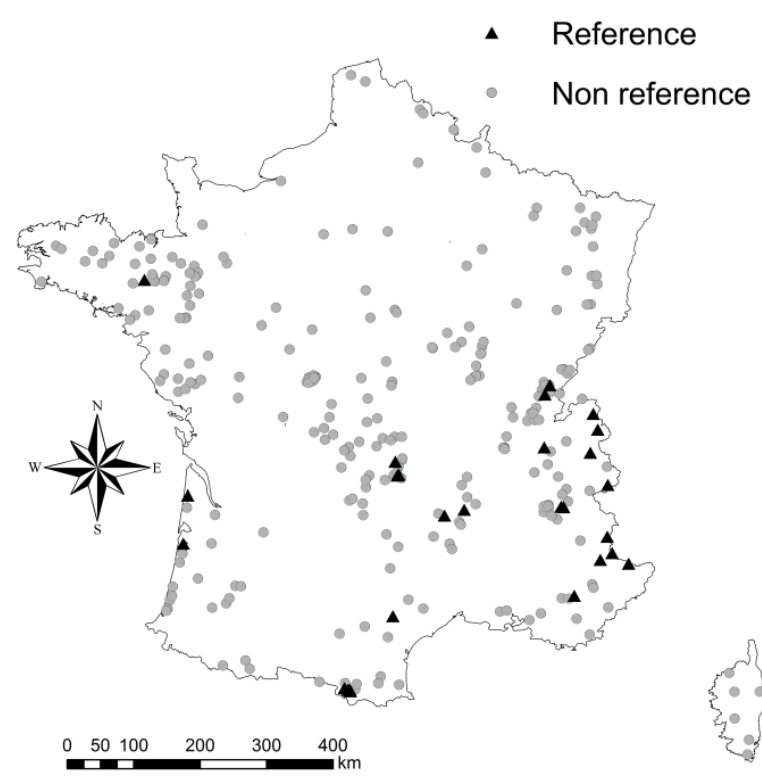

Figure 1: Study area and sites, distinguishing reference and non-reference sites

Table 1: Distribution of the floristic dataset from 2005 to 2012 in lake-years

\begin{tabular}{|l|l|l|l|l|l|l|l|l|}
\hline & 2005 & 2006 & 2007 & 2008 & 2009 & 2010 & 2011 & 2012 \\
\hline Number of lake-years & 26 & 35 & 57 & 67 & 70 & 76 & 65 & 31 \\
\hline
\end{tabular}


The dataset includes 427 lake-years, from 290 distinct lakes, sampled between 2005 and 2012 (Table 1) and was divided into two sub-datasets. It was decided to keep $60 \%$ of the dataset for the calibration sub-dataset, which include the reference dataset, and $40 \%$ for the validation sub-dataset. This repartition was done to obtain two robust sub-datasets, with a larger one for calibration, which are representative of the whole territory studied and are covering similar characteristic ranges. So, the calibration dataset, composed of 254 lake-years from 214 distinct lakes, was used to define the ecological profile of the taxa and index parameters. The reference dataset, totally included in the calibration dataset, was composed of 47 lake-years sampled on reference lakes and was used to define the reference model and fix boundaries of ecological quality classes. Finally, the validation dataset was composed of 173 lake-years and was used to confirm the response of the index to the trophic gradient and anthropogenic pressure.

Even if, regional based indices respond probably better than large scale based indices (Marchetto et al., 2009), no other sub-division of the dataset, for example by ecoregion, was made for the development of the index. Due to the high typological diversity of French lakes (depth, altitude and biogeography) it appeared difficult to distinguish homogeneous cluster with a reasonable statistical size. Thereby it was developed continuous model including typological parameters at national level on the whole French metropolitan territory. This method also has the advantage of being less subject to the threshold effect present in discrete models.

\subsection{Statistic analysis}

All statistical analyses were carried out using R (R Development Core Team, 2014). In order to be comparable, all environmental and chemical data were log transformed except land use classes on which an angular transformation (arcsine $(\sqrt{ } \mathrm{x})$ ) was applied (Legendre and Legendre, 1998).

\subsection{Development of the Algal Biomass Metric}

The algal biomass metric, MBA ("Métrique de Biomasse Algale"), was developed in the first step of the process (De Bortoli and Argillier, 2008; De Bortoli et al., 2007). It was based on total biomass evaluated by average chlorophyll-a concentration, which is a good rating of the total phytoplankton biomass available in the water body (Carvalho et al., 2012; Poikāne et al., 2010). The metric was expressed in Ecological Quality Ratio (EQR) with the ratio Chloro ${ }_{r e f} / C h l o r o$, where Chloro is the observed mean chlorophyll-a for the growing season and Choro $_{\text {ref }}$ is the reference of chlorophyll-a (in $\mu \mathrm{g} . \mathrm{I}^{-1}$ expected in reference conditions). The latter was defined with a model between mean 
chlorophyll-a and the mean depth of the water body ( $\mathrm{Z}$ in $\mathrm{m}$ ) on the French reference dataset (De Bortoli and Argillier, 2008). De Bortoli and collaborators showed that mean depth was the main factor influencing the concentration of chlorophyll-a in reference lakes. The equation model was defined following equation 1 . The chlorophyll-a reference depends on the mean depth of the lake and is thus a site-specific value.

$$
\text { Chloro }_{\text {ref }}=10^{\left[0.754-0.489 \times \log _{10}(Z)\right]}(\text { Eq. } 1)
$$

To respect the concept of the WFD, 4 quality thresholds for five ecological quality classes (High, Good, Moderate, Poor and Bad) should be defined. These EQR thresholds were based on the prediction interval of this linear model (equation 1). The MBA threshold $H / G$ was defined as the prediction interval of $90 \%$ of the model used on the reference sites. The other three thresholds are calculated directly using the distance between the reference value and the $H / G_{\mathrm{EQR}}$ value, obtained by the relation "Log $\left(\mathrm{MBA}_{\mathrm{EQR}}\right)$ - $\log (\mathrm{TP})$ ". Finally, ecological class thresholds were transformed by linear interpolation in order to fall on a linear scale $(0.2,0.4,0.6$ and 0.8$)$ for respectively Bad/ Poor, Poor/ Moderate, Moderate/Good and Good/High thresholds. Moreover, this transformation facilitates metrics aggregation in normalized EQR ( $\mathrm{nEQR}$ ) and the comparison with other European indices (Poikane et al., 2011). See Appendix A for the detailed formulae.

\subsection{Development of the Specific Composition Metric}

The specific composition metric, MCS ("Métrique de Composition Spécifique"), qualifies the trophic level of a lake from the phytoplankton communities determined during the different annual surveys. In the whole dataset, 1,417 different taxa were recorded and used for the metric development. Ecological profiles were first defined along the trophic gradient based on total phosphorus concentration for taxa determined at not less than species level and for taxa which occurred more than 25 times in dataset. These profiles were defined for each taxon by two values, the optimum and the tolerance. The values, representing the distribution of the taxon biovolume along the TP gradient, were calculated using the mean TP and the TP standard deviation for each taxon weighted by the taxon biovolume. This method is an adaptation of the weighted averaging method (ter Braak and van Dam, 1989). Total phosphorus data were log-transformed. Optima and tolerances were scaled between 0 and 20 and between 0 and 3 respectively. Finally, a box-cox transformation (Box and Cox, 1964) was applied in order to obtain a normal distribution and give a better distribution of the scores along the whole range. Thus, optima and tolerances were named respectively "specific scores" and "stenoecy coefficients". 
These values allow the calculation of the MCS metric for each campaign $\left(\mathrm{MCS}_{\mathrm{c}}\right)$ using the Zelinka and Marvan formula (1961), (Equation 2). The mean MCS is calculated on the growing period with at least 3 surveys per year.

$$
M C S_{c}=\frac{\sum_{i=1}^{n} C S_{i} \times S_{i} \times B_{i}}{\sum_{i=1}^{n} S_{i} \times B_{i}} \text { (Eq. 2) }
$$

Where $\mathrm{B}_{\mathrm{i}}$ : Biovolume of species "i" in $\mathrm{mm}^{3} \mathrm{I}^{-1}$,

$\mathrm{CS}_{\mathrm{i}}$ : Specific score of species " $\mathrm{i}$ ", from 0 to 20 ,

$S_{i}$ : Stenoecy coefficient of species "i" from 0 to 3.

The final notation determines a quality level. It is obtained by the ratio between the mean observed value of the MCS and the expected value in reference condition (Ecological Quality Ratio EQR;

Equation 3).

$$
M C S_{E Q R}=\frac{M C S}{M C S_{\text {ref }}}(\text { Eq. 3) }
$$

The $\mathrm{MCS}_{\text {ref }}$ were calculated on reference dataset with the Equation 2. The results were used to develop a model to calculate the $\mathrm{MCS}_{\text {ref }}$ for all the other lakes. After testing different models including typological and geographical parameters (mean depth, max depth, elevation, volume, residence time, latitude and alkalinity), it has been established the more relevant model with the following equation (Equation 4) which combines mean depth and altitude of the water body. Thus, reference values can be derived for all lakes and for lake types with no reference sites.

$$
\mathrm{MCS}_{\text {ref }}=10.134+2.603 \times \log _{10}(\mathrm{Z}+1)+0.3148 \times \log _{10}(\text { Alt }+1)(\text { Eq. } 4)
$$

$Z$ : the mean depth of the water body in meters

Alt: the altitude of the water body in meters.

The ecological status thresholds were defined from $\mathrm{MCS}_{\mathrm{EQR}}$ distribution on the reference dataset. The High/Good boundary was defined as the $25 \%$ quantile of the reference range according to Hering et al. (2006). The 3 other boundaries were defined by dividing the rest of the range on the calibration dataset into 4 equal classes. Finally, they were rescaled by linear interpolation by equation 5 , in order to obtain normalized EQR ( $\mathrm{MCS}_{\mathrm{nEQR}}$ ) and to fall on the same linear scale as the MBA metric.

$$
M C S_{n E Q R}=1.205 \times M C S_{E Q R}-0.3318(\text { Eq. 5) }
$$




\subsection{Metric aggregation and index validation}

The WFD requires an assessment of both abundance and taxonomic composition of the phytoplankton (European Parliament, 2000). To provide an overall assessment of this biological element, the IPLAC index, is a linear combination of the two metrics in normalized EQR (section 2.3 and 2.4). All the values of the two metrics above 1 are brought back to 1 and all the exceptional values below 0 are set at 0 before aggregation. The best ratio to aggregate MBA and MCS was determined in order to optimize the correlation between IPLAC and total phosphorus. The better correlation $\left(r^{2}\right)$ was researched between IPLAC and TP by varying the ratio of the two metrics. Finally the IPLAC, over a range from 0 to 1 , is obtained on the basis of equation 6 .

$$
I P L A C=0.7 \times M C S_{n E Q R}+0.3 \times M B A_{n E Q R}(E q .6)
$$

The IPLAC ecological status thresholds are the same as the constitutive metrics with a linear scale: High/Good 0.8; Good/Moderate 0.6; Moderate/Poor 0.4 and Poor/Bad 0.2.

To validate this assessment method, IPLAC was applied to the validation dataset (section 2.1), independent of the calibration-development dataset.

\subsection{Testing the sensitivity of the IPLAC}

The responses of the IPLAC to different types/levels of external anthropogenic pressure or trophic classification of lakes were studied. For that goal, a complementary analysis between the IPLAC and different chemical parameters and the Secchi depth was conducted. The mean concentration of total phosphorus (TP), nitrate $\left(\mathrm{NO}_{3}{ }^{-}\right)$, nitrite $\left(\mathrm{NO}_{2}{ }^{-}\right)$, ammonium $\left(\mathrm{NH}_{4}{ }^{+}\right)$, Kjeldahl nitrogen, chlorophyll-a and the mean Secchi depth during the growing period were calculated. Pearson correlations were analyzed between each parameter, the final index and its metrics. Secondly, the OECD (1982) trophic classification of lakes, based on total phosphorus (annual mean), chlorophyll-a (annual maximum and mean) and Secchi depth (annual mean), was compared with the IPLAC values of water bodies.

Then, the first classification level of Corine Land Cover (2006) was used to determine 6 classes of land use, defined in section 2.1. Pearson correlations were calculated and analyzed between these classes with IPLAC and its 2 metrics. The response of IPLAC to the population density was studied at the watershed level after logarithmic transformation.

\subsection{From a floristic point of view}


A floristic analysis was conducted to analyze the distribution of algal groups in the different IPLAC classes. First of all, the range of total biovolume and the biovolume of cyanobacteria (in $\mathrm{mm}^{3} . \mathrm{l}^{-1}$ ), according to ecological quality classes from bad to high, was observed. The relationship between biovolume and trophy was studied. Finally, boxplot representations were used to visualize biovolume ratios of different taxonomic groups versus IPLAC ecological quality classes.

\section{Results and discussion}

\subsection{Characteristics of database content}

The main physical characteristics of the datasets are summarized in Table 2. The lakes sampled have a wide range of physical characteristics including lakes in plains and mountains, and lakes that were shallow, very shallow and deep from $0.8 \mathrm{~m}$ to $309.7 \mathrm{~m}$ depth. The different catchment areas vary from 0.37 to $10,484 \mathrm{~km}^{2}$ for the general database with no significant difference between the calibration dataset and the validation dataset. Thus, the datasets used cover the whole diversity of the French territory and for the major parameters the ranges are comparable between the calibration dataset and the validation dataset. The chemical characteristics (Table 3) also present quite a wide range of values with low and high mineralization and with different trophic levels. TP

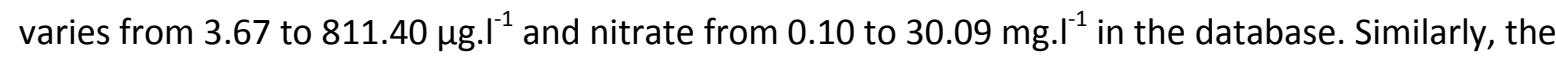
watershed characteristics from Corine Land Cover (European Union, 2006) of sampled lakes (Table 4) present wide ranges from watershed totally covered by agriculture to no agricultural area and from 0 to $100 \%$ of forest area.

Table 2: Summary of the main physical characteristics of the water bodies in the datasets available from 2005 to 2012 (with Min: minimum value, Sd: standard deviation, Max: maximum value and N: observation number)

\begin{tabular}{|c|c|c|c|c|c|c|c|}
\hline & & & Mean & $\mathrm{Sd}$ & Min & Max & $\mathrm{N}$ \\
\hline \multirow{10}{*}{ Calibration dataset } & \multirow{5}{*}{ Non reference } & Altitude (m) & 490.04 & 591.40 & 0.00 & $2,841.00$ & 214 \\
\hline & & Max depth (m) & 29.01 & 37.16 & 0.80 & 309.70 & 204 \\
\hline & & Mean depth (m) & 11.56 & 17.44 & 0.30 & 153.00 & 214 \\
\hline & & Lake area $\left(\mathrm{km}^{2}\right)$ & 5.21 & 39.85 & 0.09 & 577.12 & 214 \\
\hline & & Watershed area $\left(\mathrm{km}^{2}\right)$ & 331.10 & $1,058.85$ & 0.44 & $10,484.20$ & 209 \\
\hline & \multirow{5}{*}{ Reference } & Altitude (m) & $1,416.76$ & 814.04 & 13.00 & $2,841.00$ & 27 \\
\hline & & Max depth (m) & 33.27 & 32.71 & 3.00 & 150.00 & 27 \\
\hline & & Mean depth (m) & 14.84 & 16.13 & 1.00 & 69.00 & 27 \\
\hline & & Lake area $\left(\mathrm{km}^{2}\right)$ & 5.40 & 14.42 & 0.09 & 57.57 & 27 \\
\hline & & Watershed area $\left(\mathrm{km}^{2}\right)$ & 94.58 & 318.56 & 0.55 & $1,620.88$ & 27 \\
\hline \multicolumn{2}{|l|}{ Validation dataset } & Altitude (m) & 395.40 & 356.50 & 0.00 & $2,081.80$ & 116 \\
\hline
\end{tabular}




\begin{tabular}{|l|ccccc|} 
Max depth $(\mathrm{m})$ & 23.00 & 21.73 & 1.30 & 96.00 & 106 \\
Mean depth $(\mathrm{m})$ & 8.69 & 8.67 & 0.40 & 41.00 & 116 \\
Lake area $\left(\mathrm{km}^{2}\right)$ & 1.34 & 1.47 & 0.09 & 10.46 & 116 \\
Watershed area $\left(\mathrm{km}^{2}\right)$ & 318.68 & $1,149.45$ & 0.37 & $10,484.20$ & 113 \\
\hline
\end{tabular}

Table 3: Summary of mean chemical characteristics and Secchi depth of the water bodies in the datasets available from 2005 to 2012 (with Min: minimum value, Sd: standard deviation, Max: maximum value and N: observation number)

\begin{tabular}{|l|lllll|}
\hline & Mean & Sd & Min & Max & N \\
\hline Total Phosphorus $\left(\mu \mathrm{g} . \mathrm{I}^{-1}\right)$ & 80.06 & 127.24 & 3.67 & 811.40 & 412 \\
Chlorophyll-a $\left(\mu \mathrm{g} . \mathrm{I}^{-1}\right)$ & 14.67 & 20.30 & 0.41 & 169.00 & 396 \\
Conductivity - $25^{\circ} \mathrm{c}\left(\mu \mathrm{S} . \mathrm{cm}^{-1}\right)$ & 247.51 & 195.48 & 11.57 & $1,330.50$ & 254 \\
Kjeldahl Nitrogen $\left(\mathrm{mg} . \mathrm{I}^{-1}\right)$ & 1.49 & 1.17 & 0.15 & 9.84 & 250 \\
Ammonium (mg..$\left.^{-1}\right)$ & 0.27 & 0.64 & 0.01 & 9.36 & 268 \\
Nitrite (mg. $\left.\mathrm{I}^{-1}\right)$ & 0.05 & 0.05 & 0.01 & 0.28 & 268 \\
Nitrate (mg. $\mathrm{I}^{-1}$ ) & 2.89 & 4.48 & 0.10 & 30.09 & 268 \\
Orthophosphate (PO4) $\left(\mathrm{mg} . \mathrm{I}^{-1}\right)$ & 0.27 & 2.12 & 0.01 & 33.51 & 268 \\
Secchi depth (m) & 2.85 & 2.72 & 0.10 & 19.40 & 252 \\
\hline
\end{tabular}

Table 4: Summary of the watershed characteristics of the water bodies in the datasets available from 2005 to 2012 from Corine Land Cover 2006 and 2000 for population density (with Min: minimum value, Sd: standard deviation, Max: maximum value and $\mathrm{N}$ : observation number)

\begin{tabular}{|l|lllll|}
\hline & Mean & Sd & Min & Max & $\mathrm{N}$ \\
\hline Mean population density (people $\left./ \mathrm{km}^{2}\right)$ & 42.37 & 96.18 & 0.00 & 1142.94 & 284 \\
\% Artificial area & $3.23 \%$ & $7.29 \%$ & $0.00 \%$ & $57.38 \%$ & 284 \\
\% Agricultural area & $41.78 \%$ & $31.08 \%$ & $0.00 \%$ & $100.00 \%$ & 284 \\
\% Forest area & $46.01 \%$ & $31.48 \%$ & $0.00 \%$ & $100.00 \%$ & 284 \\
\% Humid area & $0.07 \%$ & $0.45 \%$ & $0.00 \%$ & $5.71 \%$ & 284 \\
\hline
\end{tabular}

\subsection{Optimum and tolerance}

The metric MCS is based on the weighted averaging method using total phosphorus as a proxy of the trophic gradient. For each taxon of the calibration dataset an optimum and a tolerance, used as specific score and stenoecy coefficient, was calculated. A list of 165 indicative taxa was obtained (see Appendix B) distributed in the main algal groups: Chlorophyta and Charophyta (82), diatoms (34), Chrysophyta (17), cyanobacteria (16), Dinophyta (8), Cryptophyta (5) and Euglenophyta (3). Some of 
the selected taxa have already been reported as indicator species in other indices (Marchetto et al., 2009), (Mischke et al., 2008), (Wolfram et al., 2011).

The specific values of the list are consistent with the literature. Most cyanobacteria show low specific scores whereas Dinophyta show high specific scores. Nevertheless, some differences exist with other taxonomic lists used in other European indices. 72 taxa from the taxonomic list have a specific score for the index IPLAC but not for the TI index of Norway (Ptacnik et al., 2009). The latter is more dedicated to Nordic region with oligotrophic and mesotrophic lakes and IPLAC covers a broader gradient, which can explain a larger taxonomic list.

On the other hand, up to $62 \%$ of the taxa contributing to IPLAC also contribute to the PTSI German index (Mischke et al., 2008) depending of the lake types in which more species contribute (332 species). In both indices, species or infra-species are used. The choice of not using genera in MCS was made to provide a more precise ecological assessment as already done in the PTSI. The definition of specific score and stenoecy coefficient at species level are more precise because in genera some species can be ubiquitous and others specific to a small ecological range.

In comparison with the Brettum index (Wolfram et al., 2014), the list of contributing taxa is more extended in the IPLAC. The Brettum has only 80 taxa taken into account for Austria. The lake types covered by the IPLAC are greater than for the Brettum which is applicable to Alpine types. In the Austrian method species and genus contribute to the index. This point differs with IPLAC in which only species, or infra-species, are used.

The detailed indicator list of the MCS (Appendix B) is sorted by increasing specific scores. The first part of the list is composed of taxa with low specific scores, corresponding to more eutrophic lakes. These species belong mostly to the phyla of Cyanobacteria, Euglenophyta and some Chlorophyta which is comparable with the Italian index - MedPTI (Marchetto et al., 2009). This is consistent with other literature which describes the cyanobacteria species, Microcystis aeruginosa Kützing in hydrosystems with high TP concentration usually eutrophic (Cellamare et al., 2007), (Berrada et al., 2000), (Joung et al., 2011). Planktothrix agardhii (Gomont) Anagnostidis \& J. Komárek is associated with water quality degradation in small lake (Silva et al., 2011). Its presence is favored by increasing TP concentration from sediment resuspension (Mischke, 2003). The same author describes Limnothrix redekei (Van Goor) Meffert as dominant in eutrophic lakes in association with Plantothrix agardhii. These species are indicative of high trophic status.

In contrast, only 4 cyanobacteria species in the MCS list, Aphanothece minutissima (West) Komárková-Legnerová \& Cronberg, Chroococcus limneticus Lemmermann, Synechococcus elongatus 
Nägeli and Aphanothece clathrata W. \& G.S. West are qualified as indicative of low trophic status and so appear in the last part of the list with higher specific scores. Reynolds (2006) also considered the genus Synechococcus as characteristic of low nutrient and clear water.

In the last part of the MCS taxa list are placed species sensitive to the trophic elevation, essentially Heterokontophyta (Chrysophyceae), Dinophyta and part of the Bacillariophyta, as also done in the Brettum index (Wolfram et al., 2014). Chrysophyceae are associated with cold and clear water and very low trophic status (Reynolds, 2006). This algal group is interestingly not considered in the MedPTI index (Marchetto et al., 2009). This may be explained by the geographical distribution of this algal group poorly represented in the Italian reservoir and more specific of Nordic lakes (Ptacnik et al., 2009). The genera Dinobryon, Chrysolykos, Kephyrion, Peridinium, Peridiniopsis and Cyclotella are the main representative taxa of the sensitive group with CSi values above 15.9.Three species of Peridinium, $P$. umbonatum Stein, $P$. willei Huifelt-Kaas and $P$. inconspicuum Lemmermann have quite high scores, respectively 14.4, 16.84 and 20, in agreement with the Italian index (Marchetto et al., 2009) that classifies the genus Peridinium with one of the highest trophic values.

In the PTSI, Mischke et al. (2008) highlighted 6 Peridinium species including P. umbonatum and willei but the scores for this genus are variable from 0.94 (P. willei Huifelt-Kaas) to 4.15 (P. cinctum (O.F. Muller) Ehrenberg). This variability justifies the use of species instead of genera in the bioindicator list.

The middle part of the MCS list is dedicated to the Chlorophyta, Charophyta and Cryptophyta. The former is a large algal group with many species (De Reviers, 2003) largely distributed around the world and over a broad trophic range. The CSi values for this group are around 10. Among the ubiquitous taxa there are Oocystis, different Scenedesmus, Desmodesmus and Monoraphidium species. Some Charophyta species, like Closterium and Staurastrum are also in that group which is comparable with the Brettum index or the PTSI (Wolfram et al., 2014). Five species of the phylum Cryptophyta, cosmopolitan (Klaveness, 1988) and widely distributed in terms of latitude and trophic state (Reynolds, 2006), belongs to this part of the taxon list.

\subsection{IPLAC and the trophic gradient (TP)}

The IPLAC was developed to reveal the trophic gradient of water bodies and especially the total phosphorus concentration. The two metrics $\mathrm{MBA}_{\mathrm{nEQR}}$ and $\mathrm{MCS}_{\mathrm{nEQR}}$, were significantly correlated to the total phosphorus in the calibration and validation datasets (Table 5). 


\begin{tabular}{|l|l|l|}
\hline & Calibration $(\mathrm{n}=255)$ & Validation $(\mathrm{n}=173)$ \\
\hline MCS $_{\mathrm{nEQR}}$ & $0.51^{* * *}$ & $0.4^{* * *}$ \\
\hline MBA $_{\text {nEQR }}$ & $0.3^{* * *}$ & $0.24^{* * *}$ \\
\hline IPLAC & $0.54^{* * *}$ & $0.43^{* * *}$ \\
\hline
\end{tabular}

Table 5: Pearson correlations between total phosphorus and IPLAC and its metrics on the calibration and validation datasets (*** p-value<0.001; n: number of lake-years)

According to the dataset available, a good relationship can be observed (Table 5) between IPLAC and the average concentration of total phosphorus in the growing season with an explained variance of close to 0.54 with the calibration dataset and close to 0.43 with the validation dataset. The validation dataset allows the index performance to be assessed and its application to an independent dataset (Marchetto et al., 2009) to be validated. MCS has a higher correlation coefficient with TP than MBA on both calibration and validation datasets with 0.51 and 0.4 respectively. It is interesting to note that the association of the 2 metrics, MCS and MBA, increases the explained variance of the final index. This is also the case for other indices like the Phytoplankton multimetric for unstratified Polish lakes with large catchment areas (Hutorowicz and Pasztaleniec, 2014). The relationship between IPLAC and TP is consistent with a decreasing IPLAC when TP increases, as shown in Figure 2. Such a strong relationship was also obtained with other metrics like the Size phytoplankton index (0.23), the Morpho-functional group index (0.33) and the Phytoplankton trophic index (0.67) as described in Carvalho et al. (2012) or the Phytoplankton multimetric for Polish lakes (from 0.33 to 0.70 ) described in Hutorowicz et al. (2014).

In terms of quality classes, the IPLAC showed a clear stepwise transition from high to bad status (Figure 3) along the trophic gradient (TP) on both calibration and validation dataset. Note that only one lake-year from the validation dataset was classified in bad status so the distributions in this class were not comparable. The sites with low TP concentrations during the growing season were classified in high ecological status by the IPLAC. On another hand, the sites with high TP concentrations were classified as having a worse than moderate status. This classification can be observed for other assessment methods in Europe (de Hoyos et al., 2014; Hutorowicz and Pasztaleniec, 2014; Phillips et al., 2014; Wolfram et al., 2014). 


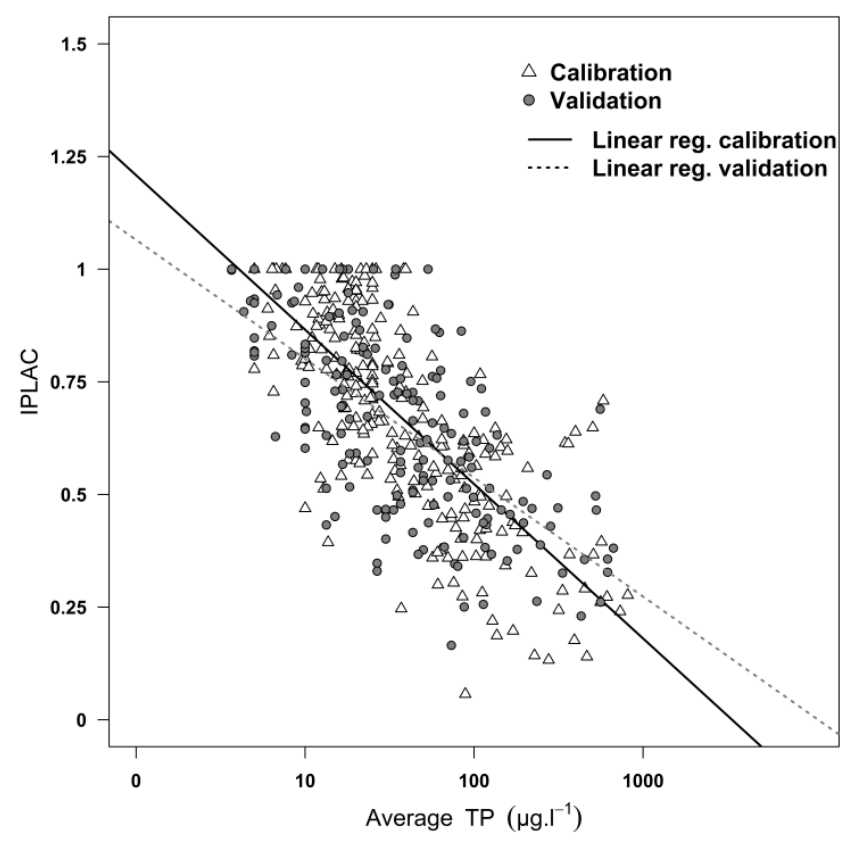

Figure 2 : IPLAC correlation with the average concentration of growing season total phosphorus (log scale in $\left.\mu g . I^{-1}\right)$ on the calibration (white) and validation (grey) datasets

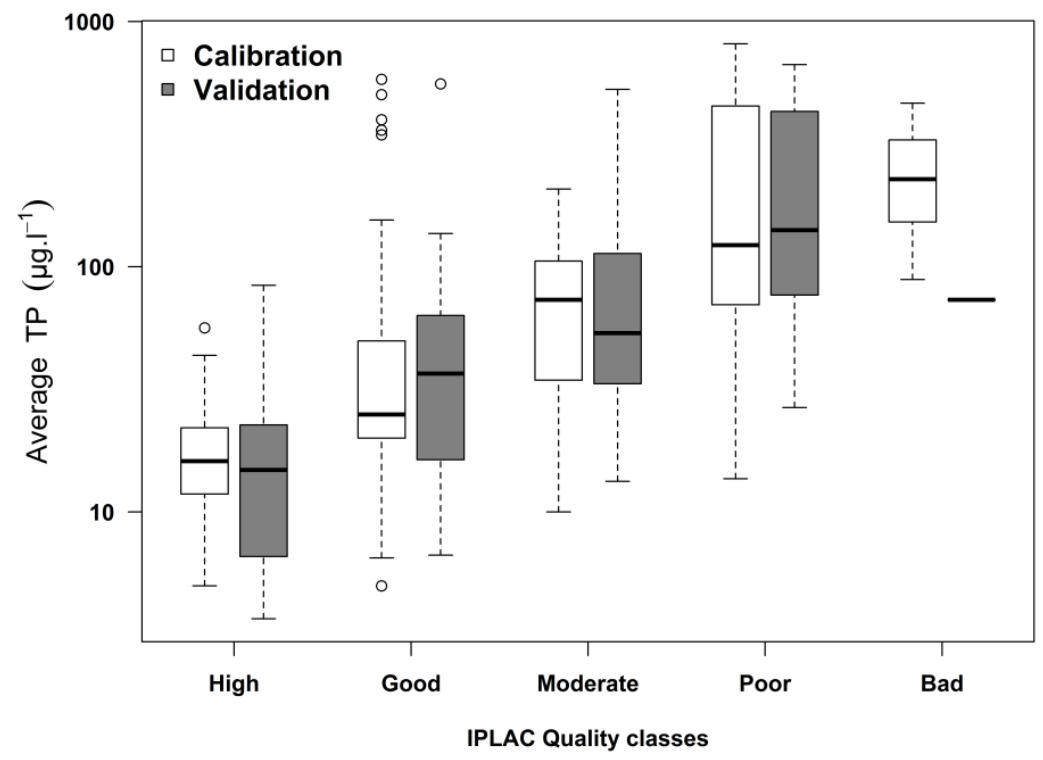

Figure 3: Range of growing season total phosphorus according to IPLAC ecological quality classes on the calibration (white) and validation (grey) dataset

\subsection{IPLAC and other water chemistry parameters}

To consolidate the IPLAC response to pressure, a correlation analysis between IPLAC and its metrics with several chemical parameters and Secchi depth was performed on both databases (calibration 
and validation). It shows very strong Pearson correlations with Secchi depth, chlorophyll-a and total phosphorus (Table 6). For Secchi and TP, coefficients are higher with the final index, above the absolute value of 0.70 , than with the separate metrics. The increase of the IPLAC index is clearly related to the increase of the transparency in the water body. With chlorophyll-a, as expected, the correlation is higher and strongest with the MBA alone, as a consequence of the construction of the metric. Secchi depth, chlorophyll-a and total phosphorus represent the trophic level of the water bodies for the OECD evaluation. Thus, these responses are compliant with the index goals even if the IPLAC results are not well distributed along the OECD trophic classification (paragraph 3.5).

Moreover, the IPLAC responded to nitrogen. This latter is the second most important parameter in the development of the phytoplankton community (Reynolds, 2006) after phosphorus. The correlation was essentially with Kjeldahl nitrogen with correlation coefficients from -0.42 for the MBA to -0.56 for the IPLAC. The correlations with ammonium (maximum -0.28) and nitrate (maximum -0.23) were weak and a little higher for nitrite. Comparable correlations were obtained for the phytoplankton multimetric for Polish lakes (Hutorowicz and Pasztaleniec, 2014) and also in other Central Baltic assessment methods (Phillips et al., 2014) similar to the IPLAC index. Usually, correlations with nitrogen forms are weaker than with phosphorus due to the fact that phosphorus is generally the limiting nutrient.

\begin{tabular}{|l|lll|}
\hline & IPLAC & MCS $_{\mathrm{nEQR}}$ & MBA $_{\mathrm{nEQR}}$ \\
\hline Conductivity & $-0.29 * * *$ & $-0.28 * * *$ & $-0.21 * * *$ \\
Kjeldahl nitrogen & $-0.56 * * *$ & $-0.54 * * *$ & $-0.42 * * *$ \\
Secchi depth & $0.73 * * *$ & $0.67 * * *$ & $0.61 * * *$ \\
Ammonium & $-0.27 * * *$ & $-0.22 * * *$ & $-0.28 * * *$ \\
Nitrite & $-0.33 * * *$ & $-0.28 * * *$ & $-0.32 * * *$ \\
Nitrate & $-0.23 * * *$ & $-0.16 * *$ & $-0.3 * * *$ \\
Total phosphorus & $-0.71 * * *$ & $-0.69 * * *$ & $-0.52 * * *$ \\
Chlorophyll-a & $-0.83 * * *$ & $-0.62 * * *$ & $-0.89 * * *$ \\
\hline
\end{tabular}

Table 6 : Pearson correlation between IPLAC, $\mathrm{MCS}_{\mathrm{nEQR}}$ and $\mathrm{MBA}_{\mathrm{nEQR}}$ with chemical parameters and Secchi (***pvalue $<0.001, * *$ p-value $<0.01$ )

\subsection{IPLAC analysis along the OECD trophic gradient}

We then compared IPLAC results to the widely accepted OECD trophic classification (1982). The database available does not contain all the necessary parameters to define the trophic status for 
each lake-year, thus, this comparison was established on a reduce dataset (198 lake-years). In France, very few lakes meet the conditions of ultra-oligotrophy and our dataset only included one high mountain lake, Lac Bleu in the Pyrenees, as ultra-oligotrophic with an IPLAC value near 1. In the 4 other OECD trophic classes, the IPLAC ranges show that only "hyper-eutrophic" lakes have a bad status. All the OECD trophic classes have lakes of High ecological quality (IPLAC $>0.8$ ). Finally, the more eutrophic the lakes, the wider the IPLAC range.

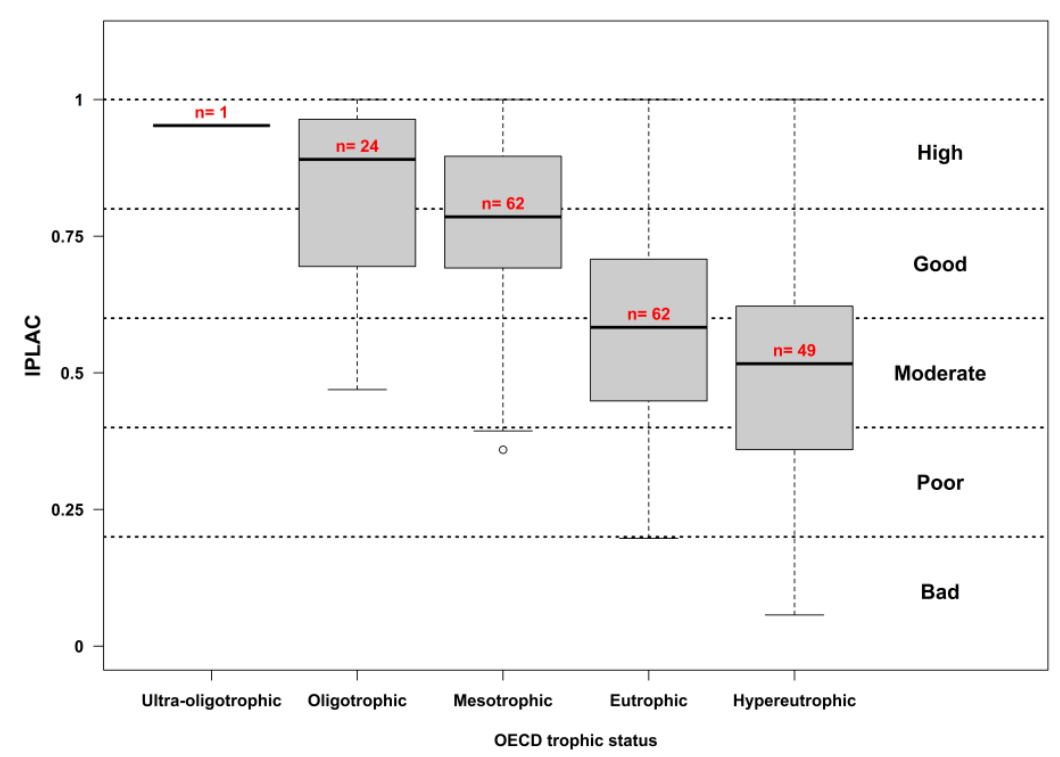

Figure 4: Range of IPLAC values according to the OECD trophic classification

\subsection{Cross analyses of IPLAC and watershed land use}

To have a more general view of the IPLAC behavior towards anthropogenic pressure, watershed land use was studied (Kuhar et al., 2011) and compared to the IPLAC score and its two metrics. Pearson correlations between each watershed land use with IPLAC and its metrics were calculated (Table 7). This analysis shows that IPLAC responds negatively to agricultural area $(-0.60)$, intensive agricultural area $(-0.47)$ and to the population density $(-0.36)$. There is no clear difference between the response to intensive and to all agricultural areas. Moreover, IPLAC responded positively to the forest area and did not respond to artificial areas or wetlands. The two metrics independently responded in the same way as the index. Katsiapi et al. (2012) in Greek lakes, showed that cyanobacteria were closely associated with artificial and agricultural land use, and that Chrysophytes and Dynophyta were closely associated to area of forest. These observations are consistent knowing that cyanobacteria are the taxonomic group the most negatively influent on the IPLAC and, inversely, Dynophyta the most positively influent (regarding the taxa scores). 


\begin{tabular}{|c|c|c|c|}
\hline & IPLAC & $\mathrm{MCS}_{\mathrm{nEQR}}$ & $\mathrm{MBA}_{\mathrm{nEQR}}$ \\
\hline Agricultural area & $-0.60^{* * *}$ & $-0.52^{* * *}$ & $-0.53^{* * *}$ \\
\hline Intensive agricultural area & $-0.47^{* * *}$ & $-0.39^{* * *}$ & $-0.43^{* * *}$ \\
\hline Artificial area & -0.04 & -0.03 & -0.01 \\
\hline Forest area & $0.57^{* * *}$ & $0.52^{* * *}$ & $0.47^{* * *}$ \\
\hline Wetland & $0.10^{*}$ & 0.08 & 0.08 \\
\hline Population density (people.m ${ }^{-2}$ ) & $-0.36^{* * *}$ & $-0.29^{* * *}$ & $-0.33^{* * *}$ \\
\hline
\end{tabular}

Table 7: Relationships (Pearson correlation) between IPLAC, MCS $_{\mathrm{nEQR}}$ and MBA $\mathrm{nEQR}_{\mathrm{R}}$ with watershed land use (***pvalue $<0.001, * *$-value $<0.01, * \mathrm{p}$-value $<0.05)$

\subsection{Floristic analysis according to IPLAC ecological status}

The IPLAC response to pressure can be analyzed more precisely through the distribution of absolute biovolumes and relative algal group biovolumes. The cyanobacteria biovolume and total phytoplankton biovolume ranges, according to IPLAC ecological status, show a clear stepwise transition from high to bad status as shown in Figure 5 . The bad status presents a total biovolume higher than in the other classes with a range between $25-100 \mathrm{~mm}^{3} . \mathrm{I}^{-1}$. At the same time, sites classified as high and good status show total biovolumes below $8 \mathrm{~mm}^{3} . \mathrm{I}^{-1}$. Some overlap is observed within the different classes. Comparable results and curves were obtained in the Central Baltic intercalibration exercise (Phillips et al., 2014) for the shallow and very shallow calcareous lake types. Values below $5 \mathrm{~mm}^{3} . .^{-1}$ were compiled for high and good classes and values from 50 to $500 \mathrm{~mm}^{3} . \mathrm{I}^{-1}$ for bad status. The relationship between total biovolume, log-transformed, and IPLAC is consistent. It is also the case for cyanobacterial biovolume but the distribution shows a different pattern. Cyanobacterial biovolume in bad statuses is clearly separate from the others with values between 10-100 $\mathrm{mm}^{3} . \mathrm{I}^{-1}$, indicating high cyanobacteria concentrations in that class. Fewer concentrations are observed in the other classes but with overlap, essentially in high to moderate classes. Similar results were found with the common metric developed for the Wiser EU FP7 project in Northern and Central Europe (Phillips et al., 2012). IPLAC does not take the intensity of blooms (no special metric) directly into account as recommended by the WFD (European Parliament, 2000). But the distribution of cyanobacterial biovolume along the IPLAC classes shows that the index already reflects the increase in algal biomass especially cyanobacteria blooms. Thus, it does not justify the use of an additional metric for blooms as in other European indices (Wolfram et al., 2014). IPLAC is then fully WFD compliant. 
In relative biovolume (Figure 6), the IPLAC ecological status classification shows a clear increase of cyanobacteria biovolume from high to bad quality and inversely a clear decrease of Dynophyta. The lakes in bad status are totally dominated by cyanobacteria. Other groups are poorly present. These lakes are quite shallow (mean depth between 1-10 $\mathrm{m}$ ) and at low altitudes (5-250 $\mathrm{m}$ ) and with a very high trophic level and high phytoplankton biomass $\left(73-557 \mu \mathrm{g} . \mathrm{I}^{-1}\right)$. Cyanobacteria are tolerant to strong anthropogenic pressure (de Hoyos et al., 2014; Reynolds, 2006). The Chrysophytes (Heterokontophyta) decrease with greater trophic availability so are positively correlated with the IPLAC values. This group is sensitive to pressure as also observed in siliceous Mediterranean reservoirs (de Hoyos et al., 2014). Green algae (Chlorophyta and Charophyta) present, like the Cryptophyta, an increase of the relative biovolume from high to moderate classes then a decrease to bad class. Diatoms (Bacillariophyta) show a different distribution along the IPLAC classes. They remain present between 15 to $45 \%$ in all classes except bad that have values below $15 \%$. This group is composed, in lakes in France, of ubiquitous species that accept low to quite high anthropogenic pressure. A quite similar distribution was observed in siliceous Mediterranean reservoirs (de Hoyos et al., 2014) and in very shallow calcareous lakes in the Central Baltic region (Phillips et al., 2014). Euglenophyta is the least represented algal group in the different IPLAC classes, globally below $10 \%$.
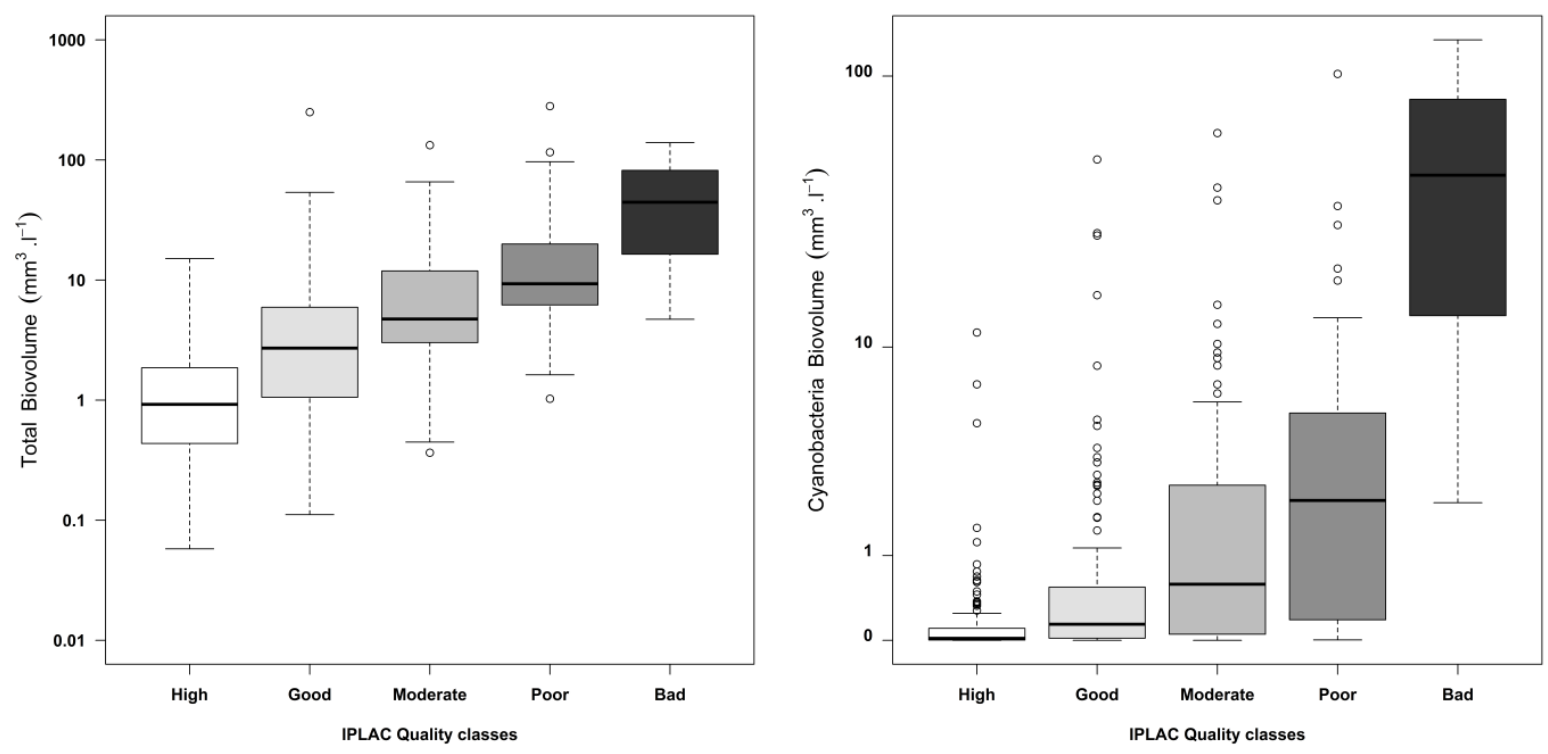

Figure 5: Total and cyanobacteria biovolume range (log-transformed) according to IPLAC ecological quality classes. Total biovolume vs IPLAC on the left and cyanobacteria biovolume vs IPLAC on the right 


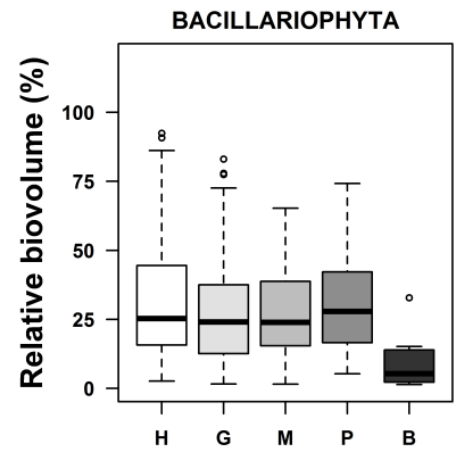

IPLAC Quality classes

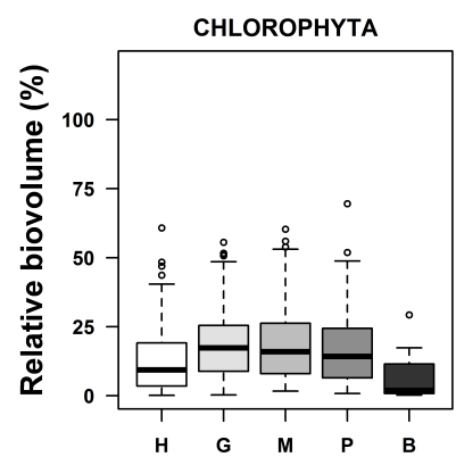

IPLAC Quality classes

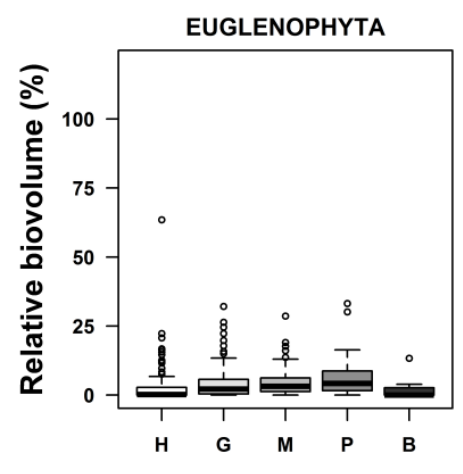

IPLAC Quality classes

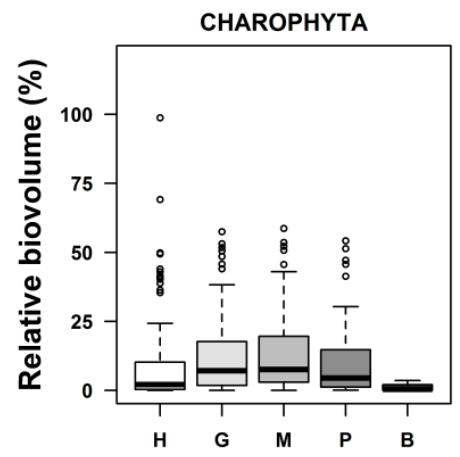

IPLAC Quality classes

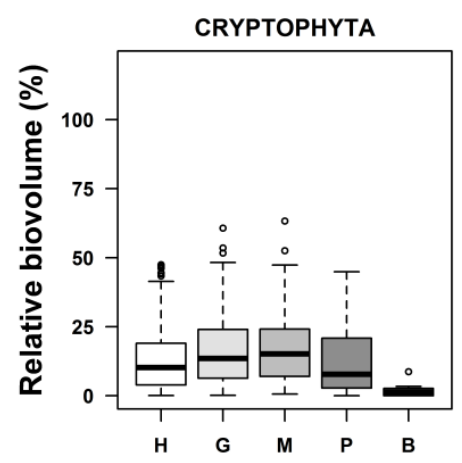

IPLAC Quality classes

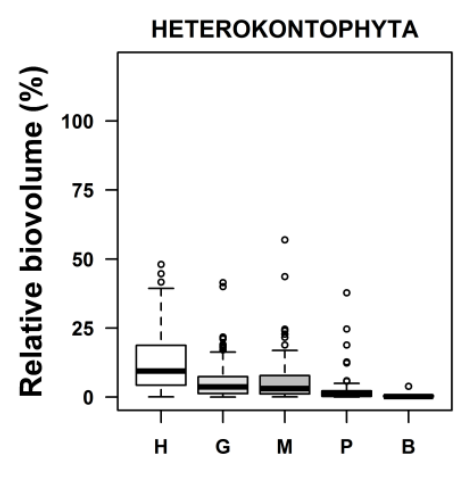

IPLAC Quality classes

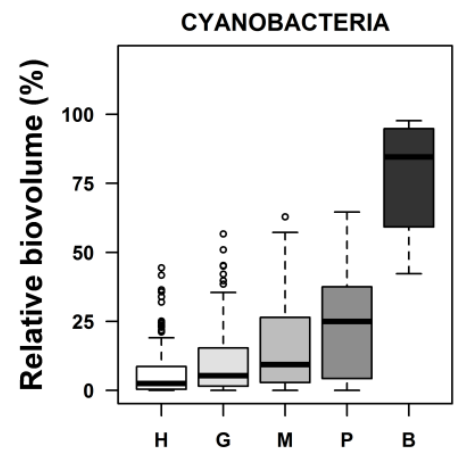

IPLAC Quality classes

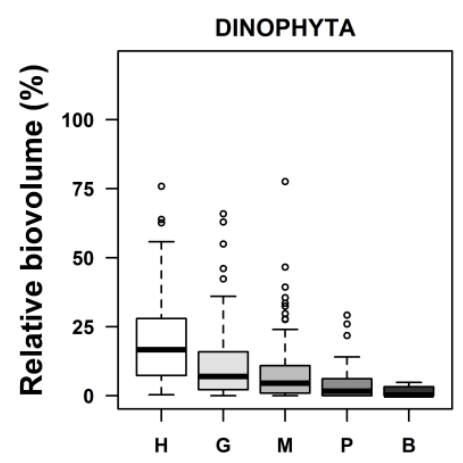

IPLAC Quality classes

Figure 6: Range of biovolume ratio (relative biovolume in percentage) of taxonomic groups according to IPLAC ecological quality classes

\section{Conclusions}

The IPLAC index is a multimetric index, based on the phytoplankton community, resulting from the aggregation by weighted sum of two normalized metrics, the MBA or total Algal Biomass Metric and the MCS or Specific Composition Metric. The first metric is based on the average concentration of chlorophyll-a during the growing season, which is a good rating of the total phytoplankton biomass available in the water. The second is based on the sampled species composition expressed in biovolume. This index can be applied to all lakes, natural or not, located in the metropolitan territory 
of France. The IPLAC completely fulfills the WFD requirements and, for that reason, can be used for the ecological assessment of lakes.

The IPLAC responds to the trophic gradient in accordance with the WFD guidelines, and consistently with particularity of French water bodies. It is especially correlated to total phosphorus, chlorophyll-a and the Secchi depth, which are the main proxies for the trophic level. Good correlations are also available with the watershed land use, essentially agricultural area and forest area.

Nevertheless, some limitations in the use of IPLAC are evident. The mean depth is a building parameter of the index, thus, the response is certainly worse for reservoirs with high level intraannual fluctuations. Reference values can be strongly impacted in these cases. Moreover, IPLAC was developed on French territory. Its application in other country, essentially with different lakes' characteristics, would require precautions.

The taxonomic list for the $M C S_{n E Q R}$ calculation has been purposefully reduced in order to keep only the ecological profile statistically valid. As a precaution, we recommend that evaluation in water bodies having very few taxa in the MCS list be considered as unreliable. Thus, we recommend the use of the index for taxonomic lists having at least five taxa in the MCS list. In order to have taxonomic lists at species level usable for the index, strong attention should be payed to the species determinations in the lab. It is essential, in case of bloom, to identify at species level, at least the dominant taxa.

Finally, IPLAC will be used by the French Ministry of Environment and the water agencies to evaluate lake ecological status (Ministère de l'environnement, 2015) with the biological quality element phytoplankton.

Acknowledgements: This work was supported by the French Ministry of the Environment (MEDDE) and funding by the "Office National de l'Eau et des Milieux Aquatiques" (ONEMA) through the convention between Irstea and ONEMA. We thank the six water agencies and private labs that participated to the collection of abiotic and biotic data. We are grateful to Maud Menay for a part of the dataset collection, Julien de Bortoli who contributed to the development of the algal biomass metric and the lake team of Irstea Aix-en-Provence for the database management. We also warmly thank Soizic Morin and Juliette Rosebery for their very constructive reading of this article. 
The metric MBA depends on the relationship between "mean depth of the water body and concentration of chlorophyll-a". Thus the calculations are specific to each water body.

$1^{\text {st }}$ step.

Determine the Reference value of chlorophyll-a (Chloro ${ }_{\text {ref }}$ in $\mu \mathrm{g} . \mathrm{I}^{-1}$ ) with equation 1.

$$
\text { Chloro }_{\text {ref }}=10^{\left[0.754-0.489 \times \log _{10}(Z)\right]}(\text { Eq. } 1)
$$

with Z: the mean depth of the water body in meters.

$2^{\text {nd }}$ step.

Calculation of $\mathrm{MBA}_{\mathrm{EQR}}$ with the equation 2.

$$
M B A_{E Q R}=\frac{\text { Chloro }_{\text {ref }}}{\text { Chloro }_{\text {mean }}}(\text { Eq. 2) }
$$

With Chloro $_{\text {mean }}$ : mean of the chlorophyll-a concentration during the growing season in $\mu \mathrm{g} . \mathrm{I}^{-1}$.

$3^{\text {rd }}$ step.

This MBA metric is built from a mathematical prediction model. Thus, the following formulae were extracted directly from the model.

Determine the threshold $\mathrm{H} / \mathrm{G}$ expressed in $\mu \mathrm{g} / \mathrm{I}$ of Chloro-a by the prediction interval with the equation 3.

$H / G_{\text {predicted }}=10^{0.754-0.489 \times \log _{10}(Z)+1.7109 \times 0.1424 \times \sqrt{1.0385+\frac{\left(\log _{10}(Z)-0.9425\right)^{2}}{4.0773}}}$

$4^{\text {th }}$ step.

Determine the other quality thresholds expressed in $\mu \mathrm{g} / \mathrm{l}$ of Chloro-a. They are derived from the relationship between $\log ($ chloro in EQR) and $\log (T P)$ with the equations 4,5 and 6.

$G / M_{\text {predicted }}=10^{0.754-0.489 \times \log _{10}(Z)+2 \times\left[1.7109 \times 0.1424 \times \sqrt{1.0385+\frac{\left(\log _{10}(Z)-0.9425\right)^{2}}{4.0773}}\right]}$ (Eq.4)

$M / P_{\text {predicted }}=10^{0.754-0.489 \times \log _{10}(Z)+3 \times\left[1.7109 \times 0.1424 \times \sqrt{1.0385+\frac{\left(\log _{10}(Z)-0.9425\right)^{2}}{4.0773}}\right]}$ (Eq.5) 


$$
P / B_{\text {predicted }}=10^{0.754-0.489 \times \log _{10}(Z)+4 \times\left[1.7109 \times 0.1424 \times \sqrt{1.0385+\frac{\left(\log _{10}(Z)-0.9425\right)^{2}}{4.0773}}\right]}
$$

$5^{\text {th }}$ step.

EQR transformation of the thresholds with the equations 7 to 10.

$$
\begin{aligned}
H / G_{E Q R} & =\frac{\text { Chloro }_{\text {ref }}}{H / G_{\text {predicted }}}(\text { Eq. 7) } \\
G / M_{E Q R} & =\frac{\text { Chloro }_{\text {ref }}}{G / M_{\text {predicted }}}(\text { Eq. 8) } \\
M / P_{E Q R} & =\frac{\text { Chloro }_{\text {ref }}}{M / P_{\text {predicted }}}(\text { Eq. 9) } \\
P / B_{E Q R} & =\frac{\text { Chloro } \text { ref }_{\text {ref }}}{P / B_{\text {predicted }}}(\text { Eq. 10) }
\end{aligned}
$$

$6^{\text {th }}$ step.

Transforming $\mathrm{MBA}_{\mathrm{EQR}}$ into normalized EQR $\left(\mathrm{MBA}_{\mathrm{nEQR}}\right)$. The equations determined are unique to each "depth / chlorophyll-a" ratio. The logarithmic regression equation that exists between the thresholds $\mathrm{MBA}_{\mathrm{EQR}}$, determined for the couple "depth / chlorophyll-a", and the normalized EQR must be determined.

Example for a water body:

Mean depth (Z): $18 \mathrm{~m}$ and Mean chlorophyll-a $\left(\right.$ Chloro $\left._{\text {mean }}\right): 3.5 \mu \mathrm{g} . \mathrm{I}^{-1}$ reported in the Table 1, 2 and 3. The logarithmic regression equation between tables 2 and 3 is equation 11.

$M B A_{n E Q R}=0.3497 \times \ln M B A_{E Q R}+1.0016(E q .11)$

\begin{tabular}{|l|c|}
\hline Table 1 & \\
\hline Chloro $_{\text {mean }}$ & 3.5 \\
\hline Chloro $_{\text {ref }}$ & 1.4 \\
\hline $\mathrm{H} / \mathrm{G}_{\text {predicted }}$ & 2.5 \\
\hline${\mathrm{G} / \mathrm{M}_{\text {predicted }}}$ & 4.4 \\
\hline $\mathrm{M} / \mathrm{P}_{\text {predicted }}$ & 7.8 \\
\hline $\mathrm{P} / \mathrm{B}_{\text {predicted }}$ & 13.9 \\
\hline & \\
\hline
\end{tabular}

\begin{tabular}{|l|c|}
\hline Table 2 & \\
\hline MBA $_{E Q R}$ & 0.4 \\
\hline Reference $_{\mathrm{EQR}}$ & 1 \\
\hline $\mathrm{H} / \mathrm{G}_{\mathrm{EQR}}$ & 0.56 \\
\hline $\mathrm{G} / \mathrm{M}_{\mathrm{EQR}}$ & 0.31818182 \\
\hline $\mathrm{M} / \mathrm{P}_{\mathrm{EQR}}$ & 0.17948718 \\
\hline $\mathrm{P} / \mathrm{B}_{\mathrm{EQR}}$ & 0.10071942 \\
\hline & \\
\hline
\end{tabular}

\begin{tabular}{|l|c|}
\hline Table 3 & \\
\hline MBA $_{n E Q R}$ & 0.68117313 \\
\hline Reference $_{n E Q R}$ & 1 \\
\hline $\mathrm{H} / \mathrm{G}_{\mathrm{nEQR}}$ & 0.8 \\
\hline $\mathrm{G} / \mathrm{M}_{\mathrm{nEQR}}$ & 0.6 \\
\hline $\mathrm{M} / \mathrm{P}_{\mathrm{nEQR}}$ & 0.4 \\
\hline $\mathrm{P} / \mathrm{B}_{\mathrm{nEQR}}$ & 0.2 \\
\hline Status classification & $\mathrm{G}$ \\
\hline
\end{tabular}


Appendix B: List of indicator taxa selected for the MCS metric in the IPLAC index with the author of the taxa, the phylum, the specific score (CSi), the stenoecy coefficient (Si) and the taxon code used in routine survey. The list is ordered by increasing CSi

\begin{tabular}{|c|c|c|c|c|c|}
\hline $\begin{array}{l}\text { Taxon } \\
\text { code }\end{array}$ & Taxon name & Author & Phylum & $\mathrm{CSi}$ & Si \\
\hline APAELA & Aphanocapsa elachista & W. \& G.S. West & Cyanobacteria & 0 & 3 \\
\hline CYSINV & Cyclostephanos invisitatus & $\begin{array}{l}\text { (Hohn \& Hellerman) Theriot } \\
\text { Stoermer \& Hakans }\end{array}$ & Bacillariophyta & 1.01 & 1.76 \\
\hline TEAINC & Tetraedron incus & (Teil.) G.M. Smith & Chlorophyta & 1.25 & 3 \\
\hline STEPAR & Stephanodiscus parvus & Stoermer \& Hakansson & Bacillariophyta & 2.44 & 2.75 \\
\hline DEDINT & Desmodesmus intermedius & (Chodat) Hegewald & Chlorophyta & 3.12 & 2.29 \\
\hline PLAAGA & Planktothrix agardhii & $\begin{array}{l}\text { (Gomont) Anagnostidis \& J. } \\
\text { Komárek }\end{array}$ & Cyanobacteria & 3.68 & 2.62 \\
\hline SCEOBL & Scenedesmus obliquus & (Turpin) Kützing & Chlorophyta & 4.43 & 2.25 \\
\hline MIOAER & Microcystis aeruginosa & Kützing & Cyanobacteria & 4.46 & 1.36 \\
\hline TRAVOP & $\begin{array}{l}\text { Trachelomonas volvocina var. } \\
\text { punctata }\end{array}$ & Y.V. Roll & Euglenophyta & 4.64 & 2.59 \\
\hline PEDDUP & Pediastrum duplex & Meyen & Chlorophyta & 5.11 & 2.08 \\
\hline $\mathrm{NIZACl}$ & Nitzschia acicularis & (Kützing) W.M.Smith & Bacillariophyta & 5.12 & 1.69 \\
\hline TERSTA & Tetrastrum staurogeniaeforme & (Schroeder) Lemmermann & Chlorophyta & 5.23 & 1.81 \\
\hline TEATRG & Tetraedron trigonum & (Nägeli) Hansgirg & Chlorophyta & 5.36 & 1.57 \\
\hline COEMIC & Coelastrum microporum & Nägeli & Chlorophyta & 5.44 & 2.21 \\
\hline CLOACU & Closterium acutum & Breb. & Charophyta & 5.51 & 2.02 \\
\hline DEDOPO & Desmodesmus opoliensis & (P.G. Richter) E.H. Hegewald & Chlorophyta & 5.76 & 2 \\
\hline CRCAPI & Crucigeniella apiculata & (Lemmermann) J. Komárek & Chlorophyta & 5.79 & 2.67 \\
\hline MONTOR & Monoraphidium tortile & (W.et G.S.West) Komárek-Legn. & Chlorophyta & 5.85 & 1.44 \\
\hline ANKFAL & Ankistrodesmus falcatus & (Corda) Ralfs & Chlorophyta & 5.87 & 1.25 \\
\hline SCESUB & Scenedesmus subspicatus & Chodat & Chlorophyta & 5.9 & 1.49 \\
\hline CHSRUF & Chrysococcus rufescens & G.A. Klebs & Heterokontophyta & 6.19 & 1.47 \\
\hline PEDTET & Pediastrum tetras & (Ehrenberg) Ralfs & Chlorophyta & 6.27 & 1.78 \\
\hline TCHALT & Tetrachlorella alternans & (G.M. Smith) Korshikov & Chlorophyta & 6.31 & 1.54 \\
\hline ACSHAN & Actinastrum hantzschii & Lagerheim & Chlorophyta & 6.41 & 2.13 \\
\hline LIMRED & Limnothrix redekei & (Van Goor) Meffert & Cyanobacteria & 6.53 & 2.07 \\
\hline TREPLA & Treubaria planctonica & (G.M.Smith) Korshikov & Chlorophyta & 6.54 & 2.26 \\
\hline
\end{tabular}




\begin{tabular}{|c|c|c|c|c|c|}
\hline DIDINE & Didymocystis inermis & (Fott) Fott & Chlorophyta & 6.68 & 1.96 \\
\hline AULGRA & Aulacoseira granulata & (Ehrenberg) Simonsen & Bacillariophyta & 7.01 & 1.99 \\
\hline STEHAN & Stephanodiscus hantzschii & Grunow & Bacillariophyta & 7.12 & 1.84 \\
\hline DEDARM & Desmodesmus armatus & (Chodat) Hegewald & Chlorophyta & 7.16 & 1.62 \\
\hline SCEECO & Scenedesmus ecornis & (Ehrenberg) Chodat & Chlorophyta & 7.2 & 1.78 \\
\hline SCEBIC & Scenedesmus bicaudatus & Dedusenko & Chlorophyta & 7.3 & 1.84 \\
\hline PEDBOR & Pediastrum boryanum & (Turpin) Menegh. & Chlorophyta & 7.34 & 1.87 \\
\hline DICEHR & Dictyosphaerium ehrenbergianum & Naeg. & Chlorophyta & 7.37 & 2.24 \\
\hline KOLLON & Koliella longiseta & (Vischer) Hindák & Chlorophyta & 7.44 & 1.79 \\
\hline DEDCOM & Desmodesmus communis & (Hegewald) Hegewald & Chlorophyta & 7.54 & 1.64 \\
\hline CRYCUR & Cryptomonas curvata & Ehrenberg emend Penard & Cryptophyta & 7.8 & 1.38 \\
\hline PSDFIN & Pseudodidymocystis fina & (Komárek) Hegewald \& Deason & Chlorophyta & 7.93 & 1.4 \\
\hline CYSDUB & Cyclostephanos dubius & (Fricke) Round & Bacillariophyta & 8.01 & 2.18 \\
\hline PHTLEN & Phacotus lenticularis & (Ehrenberg) Stein & Chlorophyta & 8.03 & 1.35 \\
\hline LAGCIL & Lagerheimia ciliata & (Lagerheim) Chodat & Chlorophyta & 8.13 & 1.89 \\
\hline PHALON & Phacus longicauda & (Ehrenberg) Dujardin & Euglenophyta & 8.15 & 1.14 \\
\hline ANYJUD & Ankyra judayi & (G.M.Smith) Fott & Chlorophyta & 8.28 & 1.76 \\
\hline CRCREC & Crucigeniella rectangularis & (Naegeli) Komárek & Chlorophyta & 8.3 & 1.69 \\
\hline OOCMAR & Oocystis marssonii & Lemmermann & Chlorophyta & 8.4 & 1.89 \\
\hline TEACAU & Tetraedron caudatum & (Corda) Ralfs & Chlorophyta & 8.41 & 1.16 \\
\hline PSELIM & Pseudanabaena limnetica & (Lemmermann) J. Komárek & Cyanobacteria & 8.44 & 1.86 \\
\hline SCEDEN & Scenedesmus denticulatus & Lagerheim & Chlorophyta & 8.51 & 1.57 \\
\hline TRAVOL & Trachelomonas volvocina & Ehrenberg & Euglenophyta & 8.7 & 1.33 \\
\hline CYCMEN & Cyclotella meneghiniana & Kützing & Bacillariophyta & 8.74 & 1.87 \\
\hline SCEOBT & Scenedesmus obtusus & Meyen & Chlorophyta & 8.92 & 1.61 \\
\hline CLOACV & Closterium acutum var. variabile & (Lemmermann) Krieger & Charophyta & 8.99 & 1.28 \\
\hline SCEACM & Scenedesmus acuminatus & (Lagerheim) Chodat & Chlorophyta & 9.01 & 1.7 \\
\hline TABFEN & Tabellaria fenestrata & (Lyngbye) Kützing & Bacillariophyta & 9.19 & 1.8 \\
\hline CCTMIN & Choricystis minor & (H. Skuja) Fott & Chlorophyta & 9.25 & 1.14 \\
\hline STXDIC & Stelexomonas dichotoma & E.W. Lackey & Heterokontophyta & 9.3 & 1.41 \\
\hline PSDPLA & Pseudodidymocystis planctonica & (Korshikov) Hegewald \& Deason & Chlorophyta & 9.41 & 1.26 \\
\hline SIDORN & Siderocelis ornata & (Fott) Fott & Chlorophyta & 9.46 & 1.4 \\
\hline APADEL & Aphanocapsa delicatissima & W. \& G.S. West & Cyanobacteria & 9.59 & 1.24 \\
\hline AULANG & $\begin{array}{l}\text { Aulacoseira granulata var. } \\
\text { angustissima }\end{array}$ & $\begin{array}{l}\text { (Ehrenberg) Simonsen (O.M.) } \\
\text { Simonsen }\end{array}$ & Bacillariophyta & 9.61 & 1.21 \\
\hline CRYOVA & Cryptomonas ovata & Ehrenberg & Cryptophyta & 9.63 & 1.8 \\
\hline MOTSIM & Monactinus simplex & (Meyen) Corda & Chlorophyta & 9.66 & 1.67 \\
\hline MERTEN & Merismopedia tenuissima & Lemmermann & Cyanobacteria & 9.83 & 1.62 \\
\hline APHFLO & Aphanizomenon flos-aquae & (Linnaeus) Ralfs & Cyanobacteria & 9.88 & 1.98 \\
\hline CLOACI & Closterium aciculare & T. West & Charophyta & 9.95 & 2.11 \\
\hline
\end{tabular}




\begin{tabular}{|c|c|c|c|c|c|}
\hline MONARC & Monoraphidium arcuatum & (Korshikov) Hindák & Chlorophyta & 10 & 1.45 \\
\hline DEDABU & Desmodesmus abundans & (Kirchner) Hegewald & Chlorophyta & 10.02 & 2 \\
\hline RDOCON & Raphidocelis contorta & $\begin{array}{l}\text { (Schmidle) Marvan, Komárek \& } \\
\text { Comas }\end{array}$ & Chlorophyta & 10.06 & 0.93 \\
\hline MELVAR & Melosira varians & C. Agardh & Bacillariophyta & 10.15 & 1.85 \\
\hline SPESCH & Sphaerocystis schroeteri & Chodat & Chlorophyta & 10.36 & 1.49 \\
\hline MONMIN & Monoraphidium minutum & (Naegeli) Komárek-legn. & Chlorophyta & 10.45 & 1.27 \\
\hline DOLFLO & Dolichospermum flos-aquae & $\begin{array}{l}\text { (Brébisson ex Bornet \& } \\
\text { Flahault) Wacklin, Hoffmann \& } \\
\text { Komárek }\end{array}$ & Cyanobacteria & 10.47 & 2.1 \\
\hline HYACON & Hyaloraphidium contortum & Pascher \& Korshikov & Chlorophyta & 10.5 & 2.21 \\
\hline MONKOM & Monoraphidium komarkovae & Nygaard & Chlorophyta & 10.6 & 1.44 \\
\hline TERTRI & Tetrastrum triangulare & (Chodat) Komárek & Chlorophyta & 10.65 & 1.46 \\
\hline OOCBOR & Oocystis borgei & Snow & Chlorophyta & 10.66 & 1.84 \\
\hline COUPLA & Coenococcus planctonicus & Korshikov & Chlorophyta & 10.68 & 1.78 \\
\hline NECROS & Nephrochlamys rostrata & Nygaard & Chlorophyta & 10.69 & 1.48 \\
\hline OOCSOL & Oocystis solitaria & Wittr. & Chlorophyta & 10.79 & 1.31 \\
\hline SCEELL & Scenedesmus ellipticus & (W \& G.S.West) Chodat & Chlorophyta & 10.95 & 1.31 \\
\hline TEAMIN & Tetraedron minimum & (Braun) Hansgirg & Chlorophyta & 10.99 & 1.38 \\
\hline DIATEN & Diatoma tenuis & C. Agardh & Bacillariophyta & 11.02 & 2.38 \\
\hline HARRET & Hariotina reticulata & Dangeard & Chlorophyta & 11.03 & 2.23 \\
\hline PLGNAN & Plagioselmis nannoplanctica & $\begin{array}{l}\text { (H. Skuja) G. Novarino, I.A.N. } \\
\text { Lucas \& S. Morrall }\end{array}$ & Cryptophyta & 11.06 & 1.33 \\
\hline WORNAE & Woronichinia naegeliana & (Unger) Elenkin & Cyanobacteria & 11.11 & 1.93 \\
\hline ENCMIN & Encyonema minutum & (Hilse in Rabh.) D.G. Mann & Bacillariophyta & 11.25 & 0.8 \\
\hline MONCON & Monoraphidium contortum & (Thur.) J. Komárek-Legn. & Chlorophyta & 11.29 & 1.24 \\
\hline OOCLAC & Oocystis lacustris & Chodat & Chlorophyta & 11.32 & 1.4 \\
\hline DICPUL & Dictyosphaerium pulchellum & Wood & Chlorophyta & 11.34 & 1.96 \\
\hline MONNAN & Monoraphidium nanum & (Ettl) Hindák & Chlorophyta & 11.36 & 1.06 \\
\hline PADMOR & Pandorina morum & Bory & Chlorophyta & 11.46 & 1.9 \\
\hline MONGRI & Monoraphidium griffithii & (Berk.) Legn. & Chlorophyta & 11.49 & 1.06 \\
\hline APAHOL & Aphanocapsa holsatica & $\begin{array}{l}\text { (Lemmermann) Cronberg \& J. } \\
\text { Komárek }\end{array}$ & Cyanobacteria & 11.59 & 1.34 \\
\hline TABFLO & Tabellaria flocculosa & (Roth) Kützing & Bacillariophyta & 11.66 & 0.98 \\
\hline OOCPAR & Oocystis parva & W.et G.S.West & Chlorophyta & 11.69 & 0 \\
\hline STACIN & Staurastrum cingulum & (West \& West) G.M.Smith & Charophyta & 11.69 & 1.77 \\
\hline CLLVUL & Chlorella vulgaris & Beij. & Chlorophyta & 11.7 & 1.26 \\
\hline LAGGEN & Lagerheimia genevensis & (Chodat) Chodat & Chlorophyta & 11.75 & 1.48 \\
\hline ANYLAN & Ankyra lanceolata & (Korshikov) Fott & Chlorophyta & 11.89 & 1.66 \\
\hline AULDIS & Aulacoseira distans & (Ehrenberg) Simonsen & Bacillariophyta & 11.92 & 1.52 \\
\hline
\end{tabular}




\begin{tabular}{|c|c|c|c|c|c|}
\hline ANYANC & Ankyra ancora & (G.M. Smith) Fott & Chlorophyta & 12 & 1.73 \\
\hline MALAKR & Mallomonas akrokomos & Pascher & Heterokontophyta & 12.02 & 1.85 \\
\hline FRACRO & Fragilaria crotonensis & Kitton & Bacillariophyta & 12.13 & 1.83 \\
\hline CRYMAR & Cryptomonas marssonii & Skuja & Cryptophyta & 12.16 & 1.63 \\
\hline CHRMIN & Chroococcus minutus & (Kützing) Nägeli & Cyanobacteria & 12.36 & 0.82 \\
\hline ULNULN & Ulnaria ulna & (Nitzsch) Compère & Bacillariophyta & 12.48 & 1 \\
\hline PLKGEL & Planktosphaeria gelatinosa & G.M. Smith & Chlorophyta & 12.66 & 1.14 \\
\hline TEATRI & Tetraedron triangulare & Korshikov & Chlorophyta & 12.75 & 2.07 \\
\hline ASTFOR & Asterionella formosa & Hassall & Bacillariophyta & 12.79 & 1.5 \\
\hline CRUTET & Crucigenia tetrapedia & (Kirchn.) W.G.S. West & Chlorophyta & 12.79 & 1.63 \\
\hline CERHIR & Ceratium hirundinella & (O.F.M.) Bergh. & Dinophyta & 12.95 & 1.38 \\
\hline PUNRAD & Puncticulata radiosa & (Lemmermann) Håkansson & Bacillariophyta & 12.98 & 1.05 \\
\hline PHTLED & Phacotus lendneri & Chodat & Chlorophyta & 13.02 & 1.94 \\
\hline DICSUB & Dictyosphaerium subsolitarium & Van Goor & Chlorophyta & 13.1 & 1.29 \\
\hline URSLON & Urosolenia longiseta & (Zacharias) Bukhtiyarova & Bacillariophyta & 13.28 & 1.74 \\
\hline AULAMB & Aulacoseira ambigua & (Grunow) Simonsen & Bacillariophyta & 13.33 & 1.86 \\
\hline ULNUAC & Ulnaria ulna var. acus & (Nitzsch.) Compère & Bacillariophyta & 13.38 & 1.35 \\
\hline SCRSET & Schroederia setigera & (Schroed.) Lemmermann & Chlorophyta & 13.44 & 1.14 \\
\hline TRETRI & Treubaria triappendiculata & Bern. & Chlorophyta & 13.54 & 1.8 \\
\hline NAVLAN & Navicula lanceolata & (C. Agardh) Ehrenberg & Bacillariophyta & 13.61 & 0.76 \\
\hline RHDLAC & Rhodomonas lacustris & Pascher \& Ruttner & Cryptophyta & 13.68 & 1.56 \\
\hline DINSOC & Dinobryon sociale & Ehrenberg & Heterokontophyta & 13.69 & 1.21 \\
\hline CYCOCE & Cyclotella ocellata & Pantocsek & Bacillariophyta & 13.81 & 1.1 \\
\hline SALFRE & Salpingoeca frequentissima & (Zach.) Lemmermann & Heterokontophyta & 14.06 & 1.91 \\
\hline PERUMB & Peridinium umbonatum & Stein & Dinophyta & 14.4 & 1.44 \\
\hline$\overline{A U L S U B}$ & Aulacoseira subarctica & (O.Muller) Haworth & Bacillariophyta & 14.56 & 1.93 \\
\hline DISPSE & Discostella pseudostelligera & (Hustedt) Houk \& Klee & Bacillariophyta & 14.57 & 0.83 \\
\hline CYCBOD & Cyclotella bodanica & Grunow & Bacillariophyta & 14.71 & 1.05 \\
\hline MONCOV & Monoraphidium convolutum & (Corda) J. Komárek - Legn. & Chlorophyta & 14.71 & 0.29 \\
\hline ERKSUB & Erkenia subaequiciliata & Pavoni & Haptophyta & 14.78 & 1.59 \\
\hline$\overline{A C N Z A C}$ & Acanthoceras zachariasii & (Brun) Simonsen & Bacillariophyta & 14.87 & 1.66 \\
\hline COEAST & Coelastrum astroideum & De Notaris & Chlorophyta & 14.94 & 1.02 \\
\hline MONCIR & Monoraphidium circinale & (Nyg.) Nygaard & Chlorophyta & 15.07 & 1 \\
\hline CYCCYC & Cyclotella cyclopuncta & Hakansson \& Carter & Bacillariophyta & 15.1 & 1.25 \\
\hline COOFOT & Coenochloris fottii & (Hindák) Tsarenko & Chlorophyta & 15.27 & 1.57 \\
\hline COCPLA & Cocconeis placentula & Ehrenberg & Bacillariophyta & 15.31 & 0.71 \\
\hline ULNDAN & $\begin{array}{l}\text { Ulnaria delicatissima var. } \\
\text { angustissima }\end{array}$ & (W.Smith) Aboal \& Silva & Bacillariophyta & 15.31 & 1.56 \\
\hline DEDGRL & Desmodesmus granulatus & $\begin{array}{l}\text { (West \& West) Hentschke \& } \\
\text { Torgan }\end{array}$ & Chlorophyta & 15.67 & 1.37 \\
\hline
\end{tabular}




\begin{tabular}{|c|c|c|c|c|c|}
\hline APOCLA & Aphanothece clathrata & W. \& G.S. West & Cyanobacteria & 15.9 & 1.12 \\
\hline DINSTI & Dinobryon sociale var. stipitatum & (Foged) Krammer & Heterokontophyta & 16.01 & 1.66 \\
\hline GYMLAN & Gymnodinium lantzschii & Utermöhl & Dinophyta & 16.2 & 1.73 \\
\hline KIROBE & Kirchneriella obesa & (W.West) Schmidle & Chlorophyta & 16.25 & 1.41 \\
\hline $\mathrm{BITCHO}$ & Bitrichia chodatii & (Reverdin) Chodat & Heterokontophyta & 16.35 & 1.89 \\
\hline KEPSPI & Kephyrion spirale & (Lackey) Conrad & Heterokontophyta & 16.38 & 1.87 \\
\hline ACDMIN & Achnanthidium minutissimum & (Kützing) Czarnecki & Bacillariophyta & 16.56 & 1.93 \\
\hline GYMHEL & Gymnodinium helveticum & Penard & Dinophyta & 16.7 & 2.24 \\
\hline PERWIL & Peridinium willei & Huifelt-Kaas & Dinophyta & 16.84 & 1.96 \\
\hline KEPMAS & Kephyrion mastigophorum & Schmidt & Heterokontophyta & 16.87 & 1.44 \\
\hline KATFUN & Katodinium fungiforme & (Anissimova) Loeblich III & Dinophyta & 17.06 & 2.07 \\
\hline CYYPLA & Chrysolykos planctonicus & B. Marck & Heterokontophyta & 17.09 & 1.92 \\
\hline DINDIV & Dinobryon divergens & Imohf & Heterokontophyta & 17.18 & 1.74 \\
\hline SYCELO & Synechococcus elongatus & Nägeli & Cyanobacteria & 17.24 & 1.88 \\
\hline CYCCOM & Cyclotella comensis & Grunow & Bacillariophyta & 17.25 & 2.3 \\
\hline CHRLIM & Chroococcus limneticus & Lemmermann & Cyanobacteria & 17.28 & 1.43 \\
\hline PEPCUN & Peridiniopsis cunningtonii & Lemmermann & Dinophyta & 17.46 & 1.77 \\
\hline DINELE & Dinobryon elegantissimum & (Korshikov) Bourrelly & Heterokontophyta & 17.73 & 2.42 \\
\hline DINSER & Dinobryon sertularia & Ehrenberg & Heterokontophyta & 18 & 1.76 \\
\hline APOMIN & Aphanothece minutissima & $\begin{array}{l}\text { (West) Komárková-Legnerová \& } \\
\text { Cronberg }\end{array}$ & Cyanobacteria & 18.02 & 2.43 \\
\hline DINCYL & Dinobryon cylindricum & Imhof & Heterokontophyta & 18.27 & 2.66 \\
\hline ELAGEL & Elakatothrix gelatinosa & Wille & Charophyta & 18.31 & 1.89 \\
\hline DISSTE & Discostella stelligera & (Cleve \& Grunow) Houk \& Klee & Bacillariophyta & 18.46 & 2.16 \\
\hline FRAARC & Fragilaria arcus & (Ehrenberg) Cleve & Bacillariophyta & 18.5 & 2.22 \\
\hline DINAME & $\begin{array}{l}\text { Dinobryon sociale var. } \\
\text { americanum }\end{array}$ & (Brunnthaler) Bachm. & Heterokontophyta & 19.23 & 2.42 \\
\hline DINBAV & Dinobryon bavaricum & Imhof & Heterokontophyta & 19.59 & 1.84 \\
\hline PERINC & Peridinium inconspicuum & Lemmermann & Dinophyta & 20 & 2.19 \\
\hline
\end{tabular}

\section{References}

AFNOR, 1999. NF T 90-117. Qualité de l'eau - Dosage de la chlorophylle a et d'un indice phéopigments. Méthode par spectrométrie d'absorption moléculaire [Water quality - Determination of chlorophyll a and of a pheopigments index. Molecular absorption spectrometric method]. p. 11. 
AFNOR, 2004. NF EN ISO 6878. Qualité de l'eau - Dosage du phosphore. Méthode spectrométrique au molybdate d'ammonium. [Water quality - Determination of phosphorus. Ammonium molybdate spectrometric method]. p. 21.

AFNOR, 2006. NF EN 15204. Qualité de l'eau - Norme guide pour le dénombrement du phytoplancton par microscopie inversée (méthode Utermöhl). [Water quality. Guidance standard on the

enumeration of phytoplankton using inverted microscopy (Utermöhl technique)]. p. 39.

Barbe, J., Lafont, M., Mallet, L., Mouthon, J., Philippe, M., Vey, V., 2003a. Actualisation de la méthode de diagnose rapide des plans d'eau : analyse critique des indices de qualité des lacs et propositions d'indices de fonctionnement de l'écosystsème lacustre. Cemagref, Lyon, p. 107.

Barbe, J., Lafont, M., Mouthon, J., Philippe, M., 2003b. Protocole actualisé de la diagnose rapide des plans d'eau. Cemagref, Lyon, p. 30.

Barbe, J., Lavergne, E., Rofes, G., Lascombe, M., Rivas, P., Bornard, C., de Benedettis, J., 1990.

Diagnose rapide des plans d'eau. Informations techniques du Cemagref 79, 1-8.

Berrada, F.D., Berrada, R., Benzekri, A., Jabry, E., 2000. Evolution saisonnière des peuplements phytoplanctoniques dans le lac-réservoir El Kansera (Maroc), en relation avec certains paramètres abiotiques et biotiques. Seasonal evolution of phytoplanktonic communities in relation to abiotic and biotic parameters in El Kansera lake-reservoir (Morroco). Hydroecol. Appl. 12, 207-231.

Box, G.E.P., Cox, D.R., 1964. An analysis of transformations (with discussion). Journal of the Royal Statistical Society 26, 211-252.

Brettum, P., 1989. Algen als Indikatoren für die Gewässerqualität in norwegischen Binnenseen [ Trans Norvegian, Meier N.G. Norvegian, 2000]. Norsk institutt for vannforskning (NIVA), Oslo, p. 102. Carvalho, L., Poikane, S., Lyche Solheim, A., Phillips, G., Borics, G., Catalan, J., De Hoyos, C., Drakare, S., Dudley, B.J., Järvinen, M., Laplace-Treyture, C., Maileht, K., McDonald, C., Mischke, U., Moe, J., Morabito, G., Nõges, P., Nõges, T., Ott, I., Pasztaleniec, A., Skjelbred, B., Thackeray, S.J., 2012. Strength and uncertainty of phytoplankton metrics for assessing eutrophication impacts in lakes. Hydrobiol. 704, 127-140.

Cellamare, M., Laplace-Treyture, C., Dutartre, A., Boutry, S., Coste, M., Delmas, F., Alard, D., Haury, J., 2007. Phytoplankton and macrophytes in two connected lakes with different trophic status in the Aquitaine region (France), 30th Congress of the International Association of Theoretical and Applied Limnology, Montreal, CAN, 12-18 August 2007, p. 1.

Coste, M., Boutry, S., Tison-Rosebery, J., Delmas, F., 2009. Improvements of the Biological Diatom Index (BDI): Description and efficiency of the new version (BDI-2006). Ecological Indicators 9, 621650.

De Bortoli, J., Argillier, C., 2008. Définition des conditions de référence et des limites des classes d'état sur la base d'une approche pressions/impacts - Plans d'eau, Paramètre chlorophylle-a.

Cemagref, p. 51.

De Bortoli, J., Daufresne, M., Argillier, C., 2007. Définition des conditions de référence sur les plans d'eau. Paramètre chlorophylle-a. Cemagref, p. 21.

de Hoyos, C., Catalan, J., Dörflinger, G., Ferreira, J., Kemitzoglou, D., Laplace-Treyture, C., Pahissa López, J., Marchetto, A., Mihail, O., Morabito, G., Polykarpou, P., Romão, F., Tsiaoussi, V., 2014. Mediterranean Lake Phytoplankton ecological assessment methods. JRC, p. 189.

De Reviers, B., 2003. Biologie et phylogénie des algues : t.2. Belin, Paris.

Dokulil, M., Teubner, K., Greisberger, M., 2005. Typenspezifische Referenzbedin-gungen für die integrierende Bewertung des ökologischen Zustandes stehender Gewässer Österreichs gemäß der EU-Wasserrahmenrichtlinie. Modul 1: Die Bewertung der Phyto-planktonstruktur nach dem BrettumIndex. Projektstudie Phase 3, Abschlussbericht. Unpubli-zierter Bericht im Auftrag des Bundesministeriums für Land- und Forstwirtschaft, Umwelt und Wasserwirtschaft, Wien. European Commission, 2011. Common implementation strategy for the Water Framework Directive (2000/60/EC). Guidance document No 14. Guidance on the intercalibration process 2008-2011, p. 103. 
European Parliament, 2000. Directive 2000/60/CE du Parlement européen et du conseil du 23 octobre 2000 établissant un cadre pour une politique communautaire dans le domaine de l'eau. Communauté Européenne, Bruxelles, p. 72.

European Union, 2000. Corine Land Cover, Mapping a Decade of Change. European Environment Agency.

European Union, 2006. SOeS, Corine Land Cover. European Environment Agency.

Fabbro, L.D., Duivenvoorden, L.J., 2000. A two-part model linking multidimensional environmental gradients and seasonal succession of phytoplankton assemblages. Hydrobiol. 438, 13-24.

Hadoux, E., Plaire, M., Esmieu, P., Dubertrand, A., Laplace-Treyture, C., 2015. PHYTOBS v2.3 : Outil de comptage du phytoplancton en laboratoire et de calcul de I'IPLAC. Version 2.3. Application JAVA. Hering, D., Feld, C.K., Moog, O., Ofenböck, T., 2006. Cook book for the development of a Multimetric Index for biological condition of aquatic ecosystems: Experiences from the European AQEM and STAR projects and related initiatives. Hydrobiol. 566, 311-324.

Hutorowicz, A., Pasztaleniec, A., 2014. Phytoplankton metric of ecological status assessment for polish lakes and its performance along nutrient gradients. Polish Journal of Ecology 62, 525-542. Joung, S.-H., Oh, H.-M., Ko, S.-R., Ahn, C.-Y., 2011. Correlations between environmental factors and toxic and non-toxic Microcystis dynamics during bloom in Daechung Reservoir, Korea. Harmful Algae 10, 188-193.

Katsiapi, M., Mazaris, A.D., 2012. Watershed land use types as drivers of freshwater phytoplankton structure. Hydrobiol. 698, 121-131.

Klaveness, D., 1988. Ecology of the Cryptomonadida - A first review, in: Sandgren, C.D. (Ed.), Growth and reproductive strategies of freshwater phytoplankton. Cambridge University press, Oxford., New York, pp. 105-133.

Kuhar, U., Germ, M., Gaberščik, A., Urbanič, G., 2011. Development of a River Macrophyte Index (RMI) for assessing river ecological status. Limnologica - Ecology and Management of Inland Waters 41, 235-243.

Laplace-Treyture, C., Barbe, J., Dutartre, A., Druart, J.C., Rimet, F., Anneville, O., 2009. Protocole standardisé d'échantillonnage, de conservation, d'observation et de dénombrement du phytoplancton en plan d'eau pour la mise en œuvre de la DCE : version 3.3.1, p. 44.

Legendre, P., Legendre, L., 1998. Numerical Ecology. Second English Edition, Amsterdam. Marchetto, A., Padedda, B., Mariani, M., Luglie, A., Sechi, N., 2009. A numerical index for evaluating phytoplankton response to changes in nutrient levels in deep mediterranean reservoirs. J. Limnol. 68, 106-121.

Ministère de l'Ecologie et du Développement Durable, 2004. Circulaire DCE 2004/08 relative à la constitution et la mise en oeuvre du réseau de sites de référence pour les eaux douces de surface (cours d'eau et plans d'eau) en application de la directive 2000/60/DCE du 23 octobre 2000 du Parlement et du Conseil établissant un cadre pour une politique communautaire dans le domaine de l'eau. Bulletin Officiel 41, 41.

Ministère de l'environnement, 2015. Arrêté du 27 juillet 2015 modifiant l'arrêté du 25 janvier 2010 relatif aux méthodes et critères d'évaluation de l'état écologique, de l'état chimique et du potentiel écologique des eaux de surface pris en application des articles R. 212-10, R. 212-11 et R. 212-18 du code de l'environnement, p. 95.

Mischke, U., 2003. Cyanobacteria associations in shallow polytrophic lakes: influence of environmental factors. Acta Oecologica 24, S11-S23.

Mischke, U., Riedmüller, U., Hoehn, E., Schönfelder, I., Nixdorf, B., 2008. Description of the German system for phytoplankton-based assessment of lakes for implementation of the EU Water Framework Directive (WFD). Univ. Cottbus, Berlin, p. 31.

OCDE, 1982. Eutrophisation des eaux: méthode de surveillance, d'évaluation et de lutte. OCDE Paris. Phillips, G., Free, G., Karottki, Y., Laplace-Treyture, C., Mischke, U., Ott, I., Pasztaleniec, A., Portielje, R., Søndergaard, M., Trodd, W., Van Wichelen, J., 2014. Central Baltic Lake Phytoplankton ecological assessment methods. JRC, p. 189. 
Phillips, G., Morabito, G., Carvalho, L., Lyche Solheim, A., Skjelbred, B., Moe, J., Andersen, T., Mischke, U., de Hoyos, C., Borics, G., 2012. Deliverable D3.1-1: Report on lake phytoplankton composition metrics, including a common metric approach for use in intercalibration by all GIGs. WISER Project, p. 61.

Poikāne, S., Alves, M., Argillier, C., van den Berg, M., Buzzi, F., Hoehn, E., de Hoyos, C., Karottki, I., Laplace-Treyture, C., Solheim, A., Ortiz-Casas, J., Ott, I., Phillips, G., Pilke, A., Pádua, J., Remec-Rekar, S., Riedmüller, U., Schaumburg, J., Serrano, M., Soszka, H., Tierney, D., Urbanič, G., Wolfram, G., 2010. Defining Chlorophyll-a Reference Conditions in European Lakes. Environmental Management 45, 1286-1298.

Poikane, S., van den Berg, M., Hellsten, S., de Hoyos, C., Ortiz-Casas, J., Pall, K., Portielje, R., Phillips, G., Solheim, A.L., Tierney, D., Wolfram, G., van de Bund, W., 2011. Lake ecological assessment systems and intercalibration for the European Water Framework Directive: Aims, achievements and further challenges. Procedia Environmental Sciences 9, 153-168.

Ptacnik, R., Solimini, A., Brettum, P., 2009. Performance of a new phytoplankton composition metric along a eutrophication gradient in Nordic lakes. Hydrobiol. 633, 75-82.

R Development Core Team, 2014. R: A language and environment for statistical computing. $R$ Foundation for Statistical Computing, Vienna, Austria.

Reynolds, C., 2006. Ecology of phytoplankton. Cambridge University Press, Cambridge, GBR. Salmaso, N., 2003. Life strategies, dominance patterns and mechanisms promoting species coexistence in phytoplankton communities along complex environmental gradients. Hydrobiol. 502, 13-36.

Silva, T., Lemaire, B.J., Vinçon-Leite, B., 2011. Suivi du phytoplancton dans les lacs urbains à l'aide d'une bouée instrumentée : Le cas du Lac d'Enghien-les-Bains, 22èmes Journées Scientifiques de l'Environnement - Reconquête des environnement urbains : les défis du 21ème siècle, Créteil. ter Braak, C.J.F., van Dam, H., 1989. Inferring pH from diatoms: a comparison of old and new calibration methods Hydrobiol. 178, 209-223.

Wolfram, G., Buzzi, F., Dokulil, M., Friedl, M., Hoehn, E., Laplace-Treyture, C., Menay, M., Marchetto, A., Morabito, G., Reichmann, M., Remec-Rekar, Š., Riedmüller, U., Urbanič, G., 2014. Alpine Lake Phytoplankton ecological assessment methods. JRC, p. 76.

Wolfram, G., Donabaum, K., Dokulil, M.T., 2011. Bewertung des ökologischen Zu-standes des Neusiedler Sees anhand des Biologischen Qualitätselements Phytoplankton. Un-publizierter Bericht im Auftrag des Bundesministeriums für Land- und Forstwirtschaft, Umwelt und Wasserwirtschaft, Wien, p. 63.

Zelinka, M., Marvan, P., 1961. Zur prazisierung der biologischen - klassifikation des Reinheit fliessender gewasser. Archiv für Hydrobiologie 57, 389-407. 